\title{
The friagem event in the central Amazon and its influence on micrometeorological variables and atmospheric chemistry
}

\author{
Guilherme F. Camarinha-Neto $^{1}$, Julia C. P. Cohen ${ }^{1,2}$, Cléo Q. Dias-Júnior ${ }^{3}$, Matthias Sörgel ${ }^{4, a}$, \\ José Henrique Cattanio $^{1,2}$, Alessandro Araújo ${ }^{5}$, Stefan Wolff ${ }^{4, b}$, Paulo A. F. Kuhn ${ }^{1}$, Rodrigo A. F. Souza ${ }^{6}$, \\ Luciana V. Rizzo ${ }^{7}$, and Paulo Artaxo ${ }^{8}$ \\ ${ }^{1}$ Postgraduate Program on Environmental Sciences - PPGCA, Federal University of Pará (UFPA), Belém, PA, Brazil \\ ${ }^{2}$ Faculty of Meteorology, Federal University of Pará (UFPA), Belém, PA, Brazil \\ ${ }^{3}$ Department of Physics, Federal Institute of Pará (IFPA), Belém, PA, Brazil \\ ${ }^{4}$ Biogeochemistry Department, Max Planck Institute for Chemistry, P.O. Box 3060, 55020 Mainz, Germany \\ ${ }^{5}$ Empresa Brasileira de Pesquisa Agropecuária (EMBRAPA), Belém, PA, Brazil \\ ${ }^{6}$ Department of Meteorology, Amazonas State University (UEA), Manaus, Amazonas, Brazil \\ ${ }^{7}$ Department of Environmental Sciences, Institute of Environmental, Chemical and Pharmaceutics Sciences, \\ Universidade Federal de São Paulo (UNIFESP), São Paulo, São Paulo, Brazil \\ ${ }^{8}$ Institute of Physics, University of São Paulo (USP), São Paulo, São Paulo, Brazil \\ ${ }^{a}$ currently at: Atmospheric Chemistry Department, Max Planck Institute for Chemistry, \\ P.O. Box 3060, 55020 Mainz, Germany \\ b currently at: Multiphase Chemistry Department, Max Planck Institute for Chemistry, \\ P.O. Box 3060, 55020 Mainz, Germany
}

Correspondence: Cléo Q. Dias-Júnior (cleo.quaresma@ifpa.edu.br)

Received: 7 June 2020 - Discussion started: 14 July 2020

Revised: 18 November 2020 - Accepted: 21 November 2020 - Published: 14 January 2021

\begin{abstract}
In the period between 9 and 11 July 2014, a friagem event reached the Amazon region. On 11 July, the southwest flow related to the friagem converged with the easterly winds in the central Amazon. The interaction between these two distinct air masses formed a convection band, which intensified over the Manaus region and the Amazon Tall Tower Observatory (ATTO) site. The satellite images show the evolution of convective activity on 11 July, which led to $21 \mathrm{~mm}$ of precipitation at the ATTO site. Moreover, the arrival of the friagem caused a sudden drop in temperature and a predominance of southerly winds, which could be seen in Porto Velho between 7 and 8 July and in Manaus and the ATTO site from 9 to 11 July. The results of ERA-Interim reanalysis and Brazilian developments on the Regional Atmospheric Modeling System (BRAMS) simulations show that this friagem event coming from the southwest, carries a mass of air with higher $\mathrm{O}_{3}$ and $\mathrm{NO}_{2}$ mixing ratios and lower $\mathrm{CO}$ mixing ratio compared to the air masses present in the central Amazon. At Lake Balbina, the friagem
\end{abstract}

intensifies the local circulations, such as the breeze phenomena. In the Manaus region and at the ATTO site, the main effects of the friagem event are a decrease in the incoming solar radiation (due to intense cloud formation), a large temperature drop and a distinct change in surface $\mathrm{O}_{3}$ and $\mathrm{CO}_{2}$ mixing ratios. As the cold air of the friagem was just in the lower $500 \mathrm{~m}$ the most probable cause of this change is that a cold pool above the forest prevented vertical mixing causing accumulation of $\mathrm{CO}_{2}$ from respiration and very low $\mathrm{O}_{3}$ mixing ratio due to photochemistry reduction and limited mixing within the boundary layer.

\section{Introduction}

The Amazon region suffers from the incursion of cold waves from the high latitudes of the Southern Hemisphere ( $\mathrm{SH}$ ), with a relatively common occurrence mainly in the less rainy season, between June and September. These events are de- 
nominated locally and in literature as friagem, and about $70 \%$ of the cases of friagem occur in this period of the year (Brinkmann and Ribeiro, 1972; Marengo et al., 1997; Fisch et al., 1998; de Oliveira et al., 2004; Caraballo et al., 2014; Ricarte et al., 2015; Viana and Herdies, 2018). Brinkmann and Ribeiro (1972) observed two to three friagem events per year, predominantly in the less rainy season, in the central Amazon. This was one of the first studies to explore frontal system (FS) interference in central Amazon.

Silva Dias et al. (2004) showed that the arrival of a friagem event in the west of the Amazon generates a pressure gradient force whose direction is opposite to the trade winds, thus causing a weakening of these winds. These authors observed that the weakening of the trade winds enables the development of vigorous local circulations in the region of Santarém (PA).

Moura et al. (2004), who used data collected on the shores of Lake Balbina (central Amazon), concluded that without the influence of large-scale flow it is possible to observe the dynamics of breeze circulations influencing the ozone $\left(\mathrm{O}_{3}\right)$ mixing ratio with more clarity. According to these authors, the $\mathrm{O}_{3}$ mixing ratio changes are larger when the flow occurs in the direction from the lake to the forest, that is, during the occurrence of the lake breeze. Trebs et al. (2012), using data from central Amazon region, concluded that the transport and dispersion of $\mathrm{O}_{3}$ mixing ratio are strongly affected by local wind systems, such as the breeze.

Marengo et al. (1997) compared the effects of the friagem at Manaus (central Amazon) and Ji-Paraná (south of the Amazon River), which are around $1200 \mathrm{~km}$ apart. They observed that the friagem was strongly modified during its passage over the Amazon basin. For example, the lower temperatures in Ji-Paraná could be associated with cold air advection, whereas in Manaus they were mainly caused by reduced solar radiation due to increased cloudiness (Viana and Herdies, 2018).

Several studies have already shown the effect of the friagem on the surface meteorological components (Fisch, 1996; Marengo et al., 1997; Fisch et al., 1998; Moura et al., 2004; Silva Dias et al., 2004). However, we are not aware of any study investigating the accompanied changes in trace gas concentrations and atmospheric chemistry in the Amazon basin. Besides that, it is known that the presence of the friagem phenomenon can alter the conditions of the local microclimate, providing the opportunity to better understand the dynamics of local circulations pattern and, consequently, influence local measurements carried out in Amazonian ecosystems, since they also cause the weakening of the predominant large-scale (trade) winds blowing from the east in the study region (Silva Dias et al., 2004).

Therefore, the objective of this study is to investigate the effects of friagem on micrometeorological variables measured in the Manaus region and in the forest region of the Amazon Tall Tower Observatory (ATTO) site (Andreae et al., 2015), as well as to evaluate the influence of this phe- nomenon on the local circulation dynamics and its role in the dispersion of trace gases at the ATTO site and Lake Balbina.

\section{Data and methodology}

\subsection{Study area}

The Sustainable Development Reserve (SDR) of Uatumã, São Sebastião do Uatumã county, where the ATTO site is located $\left(02^{\circ} 08^{\prime} 38^{\prime \prime} \mathrm{S}, 59^{\circ} 00^{\prime} 07^{\prime \prime} \mathrm{W}\right)$, is about $140 \mathrm{~km}$ northeast of Manaus in the state of Amazonas, Brazil. The village of Balbina, in Presidente Figueiredo county as well as the Balbina Dam lake $\left(01^{\circ} 52^{\prime} \mathrm{S}, 59^{\circ} 30^{\prime} \mathrm{W}\right)$, are located to the northwest of the ATTO site (Fig. 1). The ATTO site is structured in a dense terra firme forest, where plateaus prevail, with a maximum elevation of $138 \mathrm{~m}$ (Andreae et al., 2015). The artificial lake of Balbina is a flooded area of approximately $1700 \mathrm{~km}^{2}$, with an average depth of $10 \mathrm{~m}$ (Kemenes et al., 2007).

Additionally, near-surface measurements of $\mathrm{O}_{3}$ made at the $\mathrm{T} 2\left(03^{\circ} 08^{\prime} 20^{\prime \prime} \mathrm{S}, 60^{\circ} 07^{\prime} 53^{\prime \prime} \mathrm{W}\right), \mathrm{T} 3\left(03^{\circ} 12^{\prime} 49^{\prime \prime} \mathrm{S}\right.$, $\left.60^{\circ} 35^{\prime} 55^{\prime \prime} \mathrm{W}\right)$ and the forest site $\mathrm{T} 0 \mathrm{z}\left(02^{\circ} 36^{\prime} 33^{\prime \prime} \mathrm{S}\right.$, $60^{\circ} 12^{\prime} 33^{\prime \prime} \mathrm{W}$ ) experimental sites, at distances of 8,70 and $60 \mathrm{~km}$ from Manaus, respectively, were used (Fig. 1). These sites were deployed in the Observations and Modeling of the Green Ocean Amazon (GoAmazon2014/5) experiment (Martin et al., 2016). Due to its location, site T2 is heavily impacted by the Manaus urban plume as well as emissions from brick factories and to a minor extent by local pollution sources such as shipping or burning of household waste and wood near the site (Martin et al., 2016). Site T3 is typically downwind of Manaus city, influenced by urban air masses $38.5 \%$ of the time (Trebs et al., 2012; Martin et al., 2016; Thalman et al., 2017). Site T0z, typically upwind of Manaus (Rizzo et al., 2013), is situated in the Cuieiras Biological Reserve (ZF2) which has been a central part of Amazonian ecology and climate studies for over 20 years (Araújo et al., 2002). In contrast to $\mathrm{T} 2$ and $\mathrm{T} 3$, the $\mathrm{T} 0 \mathrm{z}$ site is subject to minimal anthropogenic interference. These five sites will enable us to better understand the role of friagem at near-surface $\mathrm{O}_{3}$ levels in different parts of the central Amazon, some of them in the Manaus pollution plume (Cirino et al., 2018).

\subsection{Data}

A friagem event that occurred between 9 and 11 July 2014 in the region of the ATTO experimental site was identified and used as a case study. The two main motivations for choosing this period were that (i) July is one of the months with the largest number of cold fronts that arrive in the southsoutheastern region of Brazil, and consequently, July is also a month with a high number of friagem events in the Amazon region (Prince and Evans, 2018). (ii) Throughout 2014, the intensive activities of the GoAmazon project took place (Martin et al., 2016); that is, measurements of gases and ther- 


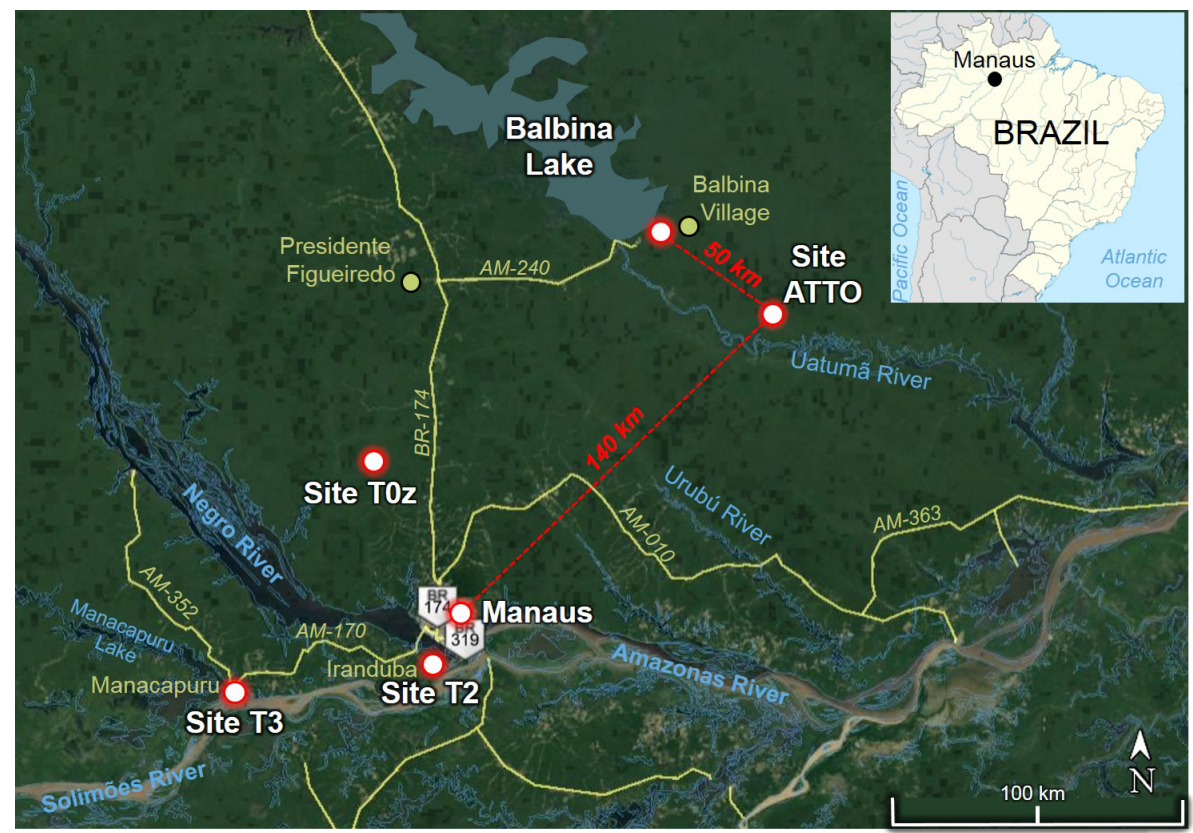

Figure 1. Google Earth map of the location of the ATTO site, Lake Balbina, T2, T3 and T0z (white circles). The dashed red line indicates the distance from the ATTO site in relation to Lake Balbina and the city of Manaus (copyright: () Google Maps). The yellow lines represent the roads and the blue lines represent the network of the rivers in this region.

modynamics of the atmosphere were carried out in various sites investigated in this work (T2, T3 and T0z). We also emphasize that the month of July 2014 did not show significant changes in precipitation and air temperature in relation to other years' July months. In addition, in 2014, there were no El Niño and La Niña phenomena (http://climanalise. cptec.inpe.br/ rclimanl/boletim/pdf/pdf14/jul14.pdf, last access: 7 April 2020).

The data were collected at the ATTO site and at the international airports of Manaus $\left(03^{\circ} 02^{\prime} 08^{\prime \prime} \mathrm{S}, 60^{\circ} 02^{\prime} 47^{\prime \prime} \mathrm{W}\right)$ and Porto Velho $\left(08^{\circ} 42^{\prime} 50^{\prime \prime} \mathrm{S}, 63^{\circ} 53^{\prime} 54^{\prime \prime} \mathrm{W}\right)$ for July 2014 . Air temperature data, as well as wind direction and wind speed, in $30 \mathrm{~min}$ intervals were obtained from airport weather stations. The cities of Porto Velho (about $930 \mathrm{~km}$ southwest of the ATTO site) and Manaus (about $150 \mathrm{~km}$ southwest of the ATTO site) were chosen with the purpose of evaluating the impacts of the advance of the friagem towards the region of the ATTO site.

The ATTO site's air temperature, wind speed, wind direction, incident shortwave radiation and precipitation were measured at the $81 \mathrm{~m}$ high walk-up tower $\left(02^{\circ} 08^{\prime} 39^{\prime \prime} \mathrm{S}\right.$, $58^{\circ} 59^{\prime} 59^{\prime \prime} \mathrm{W}$ ) at different heights (see Table 1). $\mathrm{CO}_{2}$ and $\mathrm{O}_{3}$ measurements were taken at 81 and $79 \mathrm{~m}$ above ground, respectively. The measurements of $\mathrm{CO}_{2}$ and $\mathrm{O}_{3}$ mixing ratios were conceived, respectively, by an infrared gas analyzer (IRGA, LI-7500A model, LI-COR Inc., USA) and an ultraviolet gas analyzer (TEI 49i model, Thermo Electron Corp, USA).
The data acquisition at the tower was performed by CR1000 and CR3000 data loggers (Campbell Scientific Inc., USA), with instantaneous measurements taken every minute for meteorological variables and at high frequency for $\mathrm{CO}_{2}$ $(10 \mathrm{~Hz})$ and $\mathrm{O}_{3}(30 \mathrm{~s})$ mixing ratios, and subsequently processed every $30 \mathrm{~min}$. The variables used in this study and their respective sensors are presented in more detail in $\mathrm{Ta}$ ble 1.

The $\mathrm{O}_{3}$ data at the $\mathrm{T} 3$ site were obtained as part of the US Department of Energy Atmospheric Radiation Measurement Program (ARM; http://www.arm.gov/measurements, last access: 7 April 2020) during the GoAmazon 2014/5 project (Martin et al., 2016). $\mathrm{O}_{3}$ mixing ratios were measured with an ultraviolet gas analyzer (TEI 49i model, Thermo Electron Corp, USA). The instrument was installed at a height of $3.5 \mathrm{~m}$ above the ground (Dias-Júnior et al., 2017). At T2 and $\mathrm{T} 0 \mathrm{z}, \mathrm{O}_{3}$ mixing ratios were also measured with the same analyzer model (Thermo 49i) at a height of 12 and $39 \mathrm{~m}$ a.g.l., respectively.

The $\mathrm{O}_{3}$ measurements were performed at different heights at the sites investigated here. These heights may affect the observed $\mathrm{O}_{3}$ concentrations in some cases, due to the process of dry deposition onto available surfaces and stomatal uptake by vegetation. In the case of the $\mathrm{T} 2$ and $\mathrm{T} 3$ sites, which are not forest sites, the measurement height may not have a significant influence on $\mathrm{O}_{3}$ concentrations during the day in a wellmixed boundary layer. At forest sites, previous studies have shown a significant $\mathrm{O}_{3}$ vertical gradient inside the canopy, especially in its lowest half part (Rummel et al., 2007; Freire 
Table 1. Variables used in this study, their respective measuring instruments and height in the micrometeorological tower at the ATTO site.

\begin{tabular}{llc}
\hline Variables & Instruments & Height \\
\hline Air temperature & $\begin{array}{l}\text { Thermo-hygrometer } \\
\text { (CS215, Campbell Scientific, USA) }\end{array}$ & $81 \mathrm{~m}$ \\
\hline $\begin{array}{l}\text { Wind speed } \\
\text { and direction }\end{array}$ & $\begin{array}{l}\text { 2-D sonic anemometer } \\
\text { (Windsonic, Gill Instruments Ltd., UK) }\end{array}$ & $73 \mathrm{~m}$ \\
\hline $\begin{array}{l}\text { Incident short- } \\
\text { wave radiation }\end{array}$ & $\begin{array}{l}\text { Pyranometer } \\
\text { (CMP21, Kipp and Zonen, the Netherlands) }\end{array}$ & $75 \mathrm{~m}$ \\
\hline Rainfall & $\begin{array}{l}\text { Pluviometer } \\
\text { (TB4, Hydrological Services Pty. Ltd., Australia) }\end{array}$ & $81 \mathrm{~m}$ \\
\hline $\mathrm{CO}_{2}$ mixing ratio & $\begin{array}{l}\text { Infrared gas analyzer } \\
\text { (IRGA, LI-7500/LI-7200, LI-COR Inc., USA) }\end{array}$ & $81 \mathrm{~m}$ \\
\hline $\mathrm{O}_{3}$ mixing ratio & $\begin{array}{l}\text { Ultraviolet gas analyzer } \\
\text { (TEI 49i, Thermo Electron Corp., USA) }\end{array}$ & $79 \mathrm{~m}$ \\
\hline
\end{tabular}

et al., 2017). However, the reported $\mathrm{O}_{3}$ measurements at $\mathrm{T} 0 \mathrm{z}$ and ATTO were taken above the canopy, where vertical gradients are expected to be close to zero if the boundary layer is well mixed.

The European Centre for Medium-Range Weather Forecasts (ECMWF) ERA-Interim reanalysis was used at intervals of $6 \mathrm{~h}$, with the objective of evaluating the evolution of the friagem event investigated in this work. The ERA-Interim model and the ECMWF reanalysis system present spatial resolution with 60 vertical levels, harmonic spherical representation for the basic dynamic fields and a reduced Gaussian grid with uniform spacing of approximately $79 \mathrm{~km}$ for the surface (Berrisford et al., 2011). Furthermore, enhanced images of the infrared channel of the GOES 13 satellite were used, with the purpose of analyzing the formation and passage of convective systems in the study area.

\subsection{Experimental design}

The numerical simulations of the present study were made using the BRAMS (Brazilian developments on the Regional Atmospheric Modeling System) mesoscale model version 5.3 (Freitas et al., 2017). BRAMS represents a Brazilian version of the Regional Atmospheric Modeling System (RAMS) (Cotton et al., 2003) adapted to tropical conditions. This version of BRAMS contains the coupling of the JULES (Joint UK Land Environment Simulator) (Best et al., 2011; Clark et al., 2011) and CCATT (Coupled Chemistry-AerosolTracer Transport) models (Longo et al., 2010; Freitas et al., 2009), making BRAMS a new and fully coupled numerical system of atmosphere-biosphere-chemical modeling, called JULES-CCATT-BRAMS (Moreira et al., 2013).

The integration time of the model was $72 \mathrm{~h}$, starting at 00:00 UTC on 9 July 2014. The numerical experiment was performed using only a grid whose horizontal resolution was $1.5 \mathrm{~km}$, with 185 points on $x, 140$ points on $y$ and 39 points

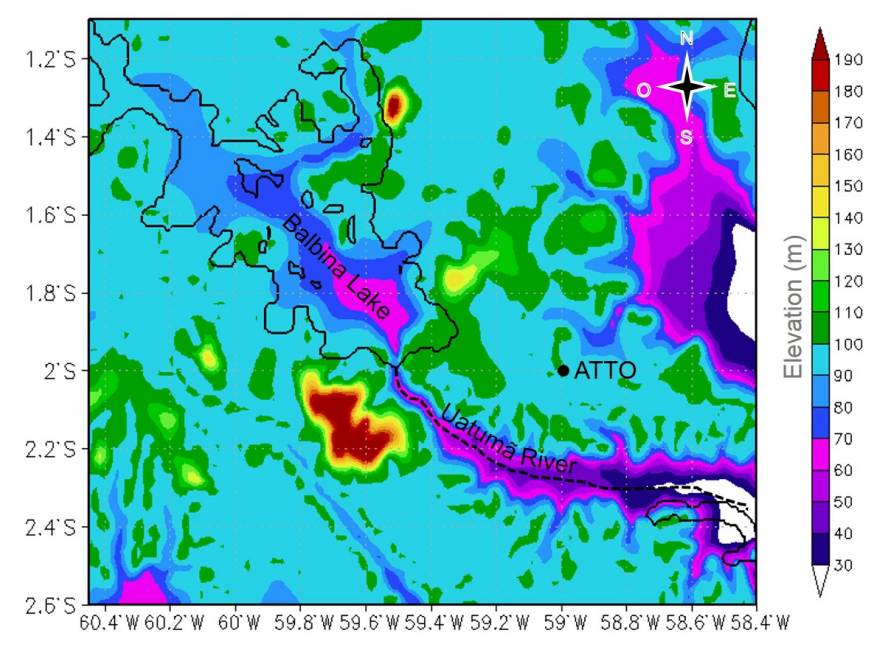

Figure 2. Domain of the grid used in JULES-CCATT-BRAMS simulation showing the distribution of the topography $(\mathrm{m})$ and location of Lake Balbina (black line), the ATTO site (black point) and Uatumã River (dashed line).

on $z$. The vertical grid resolution was variable with the initial vertical spacing of $50 \mathrm{~m}$, increasing by a factor of $1.1 \mathrm{up}$ to the $1.2 \mathrm{~km}$ level, and from that point forward this spacing was constant to the top of the model (around $16 \mathrm{~km}$ ). The domain covered by this grid, the distribution of the main rivers and topography can be observed in Fig. 2.

The initialization of the model was heterogeneous, using the ECMWF ERA-Interim reanalysis (https://www. ecmwf.int/en/forecasts/dataset/ecmwf-reanalysis-v5, last access: 7 April 2020) every $6 \mathrm{~h}$ in a $0.25^{\circ}$ spatial resolution. Seven soil layers were defined up to the depth of $12.25 \mathrm{~m}$ and the assumed soil humidity was heterogeneous, as described in Freitas and Freitas (2006). Soil texture data were originally obtained from the Food and Agriculture Organization of the 
United Nations (UN FAO) and were adapted for the Brazilian territory by Instituto Nacional de Pesquisas Espaciais (INPE) (Rossato et al., 2004).

In this simulation, cloud microphysics uses the Thompson cloud water single-moment formulation, which consists of the separate treatment of five classes of water that are then mixed in a single treatment for each type of cloud (Thompson et al., 2008; Thompson and Eidhammer, 2014). In addition, it includes the activation of aerosols in the cloud condensation nuclei (CCN) and ice nuclei (IN); thus, it predicts the concentration of the number of water droplets in the clouds, as well as the concentrations of two new aerosol variables, one for $\mathrm{CCN}$ and one for IN. These variables are grouped into hygroscopic aerosols called "water friendly" and nonhygroscopic aerosols are "ice friendly" (Freitas et al., 2017).

The parameterization of the long- and shortwave radiation used was CARMA (Community Aerosol and Radiation Model for Atmospheres) (Toon et al., 1989). This scheme solves the radiative transfer using the two-flux method and includes the main molecular absorbers (water vapor, $\mathrm{CO}_{2}$, $\mathrm{O}_{3}$ and $\mathrm{O}_{2}$ ) and treats the gas absorption coefficients using an exponential sum formula (Toon et al., 1989). The JULESCCATT-BRAMS radiation schemes are coupled online with the cloud and aerosol microphysics models to provide simulations of aerosol-cloud-radiation interaction (Freitas et al., 2017). The physical and optical properties of the cloud in the radiative scheme of CARMA were parameterized according to Sun and Shine (1994), Savijärvi et al. (1997) and Savijärvi and Räisänen (1998) using liquid and ice water content profiles provided by the JULES-CCATT-BRAMS cloud microphysics scheme (Freitas et al., 2017).

\section{Results and discussion}

\subsection{Environmental characteristics in the Amazon basin scale}

From the ECMWF ERA-Interim reanalysis, the evolution of the horizontal wind and air temperature near the surface, in the north region of Brazil, between 6 and 11 July 2014, at 12:00 UTC (local time equal to 00:00 UTC - 4 h) (Fig. 3) can be obtained. On 6 July, it is observed that the mean temperature was of the order of $24^{\circ} \mathrm{C}$ in three places of interest of this work: Porto Velho, Manaus and the ATTO site (Fig. 3a). The dominant wind direction was from the east in practically the entire Amazon region. The surface temperature and wind direction represent the standard normally found in this region (Fisch et al., 1998; Pöhlker et al., 2019). However, on 7 July, the dominant wind direction becomes south-southeast in the region of Porto Velho, as is evidenced by the presence of a mass of air with a lower temperature (around $18^{\circ} \mathrm{C}$ ) approaching this city (Fig. 3b).

Over the course of the days, between 8 and 9 July, the mass of cold air advanced even more towards Porto Velho, just as the dominant wind direction changed to south in all western regions of the state of Amazonas, as well as to the southern regions of Manaus and the ATTO site (Fig. 3c, d). On 10 July, the southerly winds arrived in the Manaus region and the ATTO site, characterizing the arrival of friagem in the area of interest of this work (Fig. 3e, f). For this period, the Centro de Previsão do Tempo e Estudos Climáticos (CPTEC) technical bulletin reported the penetration of a polar air mass in the subtropical and tropical Brazilian regions that advanced in the southeast-northwest of Brazil, giving origin to the cold waves of the south, as well as causing the friagem phenomenon in the Amazon (http://tempo.cptec. inpe.br/boletimtecnico/pt, last access: 7 April 2020).

Therefore, the arrival of the friagem phenomenon in the Amazon region is characterized by the change in the wind direction in the southwest and central regions of the Amazon and by abrupt drops in the values of temperature, especially in the southwest. Similar results were also found by other authors (Fisch, 1996; Marengo et al., 1997; Fisch et al., 1998; de Oliveira et al., 2004; Ricarte et al., 2015; Viana and Herdies, 2018).

The wind behavior throughout the Amazon basin before and during the friagem event is represented in Fig. 3a and $\mathrm{f}$, respectively. Interestingly, at the time the friagem was present in the Manaus and ATTO site regions, there was convergence of the easterly winds with the westerly flow associated with the friagem (Fig. 3f). The easterly flow carries humidity from the Atlantic coast to the central region of the Amazon, while the southerly flow, associated with the friagem event, transports masses of dry and cold air from high latitudes to the Amazon region (Marengo et al., 1997).

Figure 4 shows the satellite images before and during the friagem event in the central Amazon. Convection in the confluence between Amazonas and Tapajós rivers region was observed at dawn, on 11 July at 07:00 UTC (Fig. 4a). This convection propagated in the western direction, arriving in the ATTO site region at 13:00 UTC (Fig. 4c). Since this convective system is not associated with the squall lines that form along the coast (Cohen et al., 1995; Alcântara et al., 2011; Melo et al., 2019), it is possible to state that this convection has its formation associated with the convergence of these two air masses with different properties (Fig. 3f). It is noteworthy that during the propagation of this convection on 11 July, it intensified and caused the highest rainfall (starting at 12:30 UTC) registered at the ATTO site during the month of July 2014, with a record rainfall of $21 \mathrm{~mm}$.

The evolution of the horizontal wind and $\mathrm{O}_{3}$ mixing ratio near the surface (both from ECMWF ERA-Interim reanalysis), during 7 and 11 July 2014, at 18:00 UTC, can be seen in Fig. 5. From 7 July onward, the friagem event carried air rich in $\mathrm{O}_{3}$ from southeastern Brazil (not shown here) northwards (Fig. 5a). This air mass reached the state of the Amazonas on 8 July (not shown here). On 11 July at 12:00 UTC (not shown here), the air mass influenced by the friagem had the shortest distance from the study region (ATTO site). On 11 July 
(a) 6 July 2014, 12 UTC

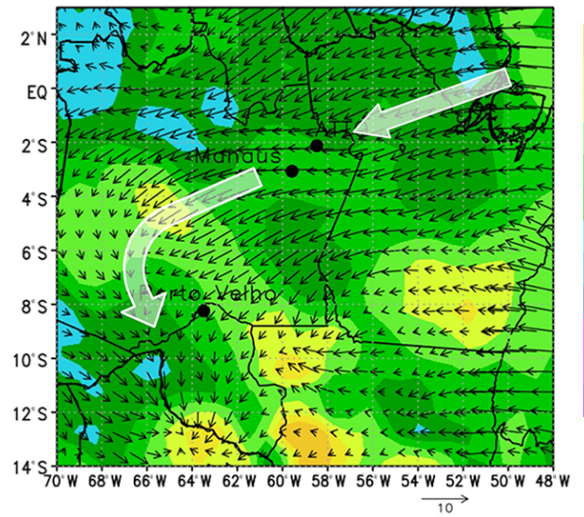

(c) 8 July 2014,12 UTC

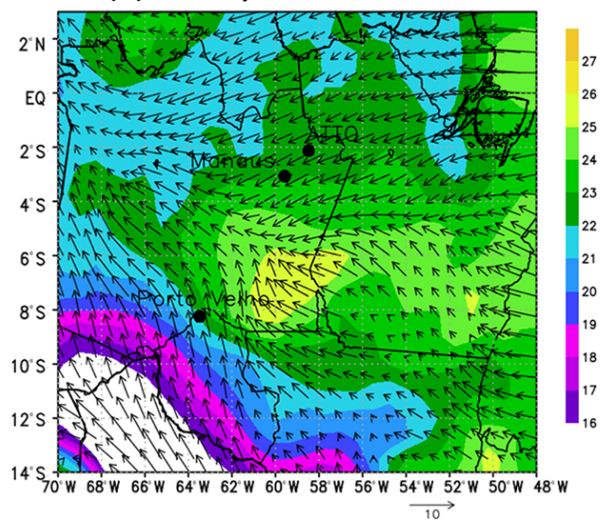

(e) 10 July 2014, 12 UTC

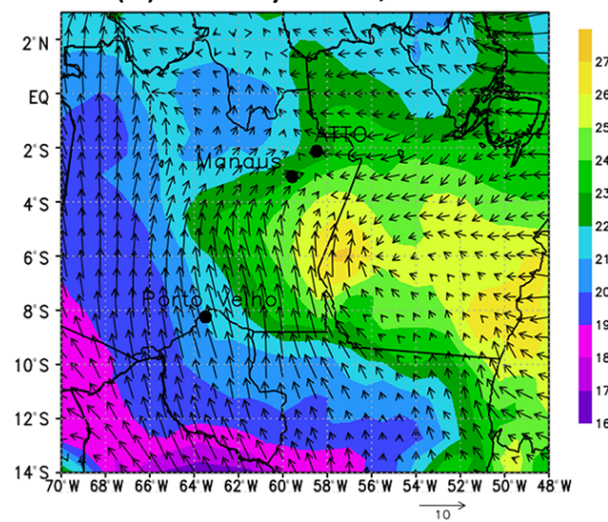

(b) 7 July 2014, 12 UTC

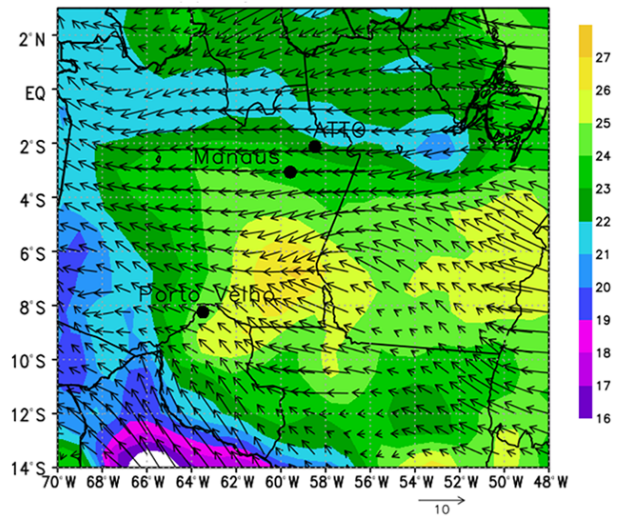

(d) 9 July 2014, 12 UTC

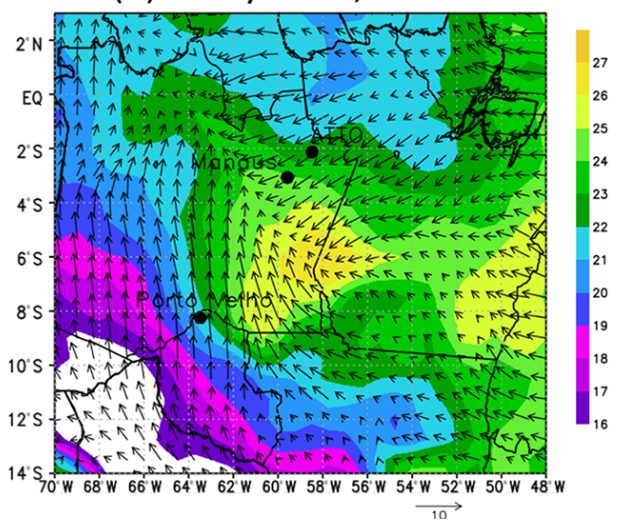

(f) 11 July 2014, 12 UTC

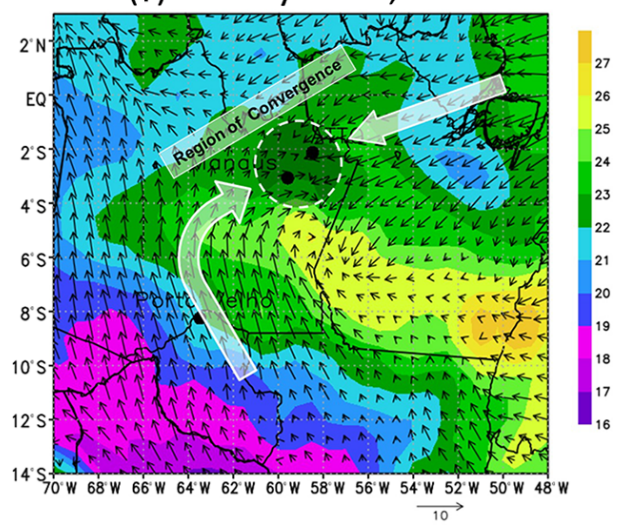

Figure 3. Distribution of air temperature $\left({ }^{\circ} \mathrm{C}\right.$, shaded) and wind $\left(\mathrm{m} \mathrm{s}^{-1}\right.$, vector) at the surface, in the localities of Porto Velho, Manaus and the ATTO site, at 12:00 UTC between 6 and 11 July 2014 obtained with the ERA-Interim reanalysis. Grey arrows indicate the predominant wind flow and the dashed circle highlights the region of convergence of the winds in the Manaus and ATTO regions.

at 18:00 UTC, the friagem began to dissipate (Fig. 5b). However, it should be noted that this mass of air rich in $\mathrm{O}_{3}$ did not reach the Manaus region and the ATTO site. It is believed that the presence of the cloud cover in central Amazonia on 11 July (Fig. 4), formed by the convergence of air (friagem and eastern winds), had an inhibitory effect on $\mathrm{O}_{3}$ formation (Betts et al., 2002). As $\mathrm{O}_{3}$ deposition prevailed, a net loss of ozone is expected during transport under conditions of limited photochemical production. The rainforest canopy is a strong sink for ozone (Jacob and Wofsy, 1990; Fan et al., 1990; Rummel et al., 2007). Therefore, the low $\mathrm{O}_{3}$ mixing ratio in the Manaus region and the ATTO site during 11 July (Fig. 5f) would be associated with cloudiness and prolonged transport over forested regions.

Marengo et al. (1997) investigated the two strongest friagem events that occurred during the year 1994, on 26 June 
(a) 11 July 2014,07 UTC

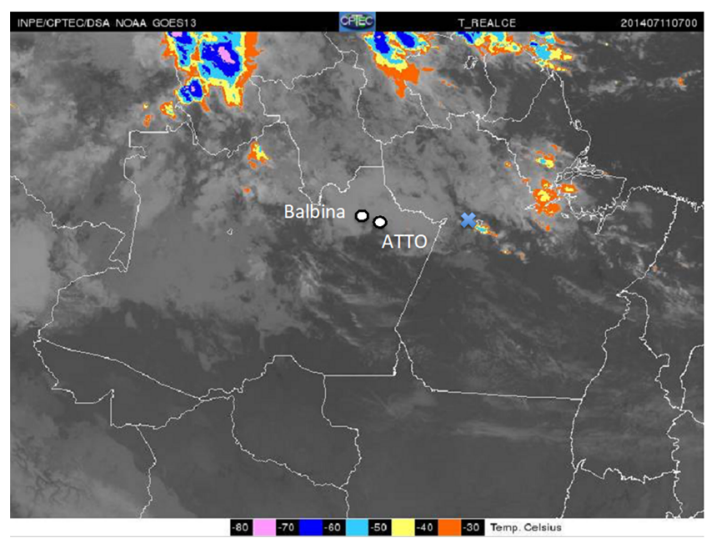

(c) 11 July 2014,13 UTC

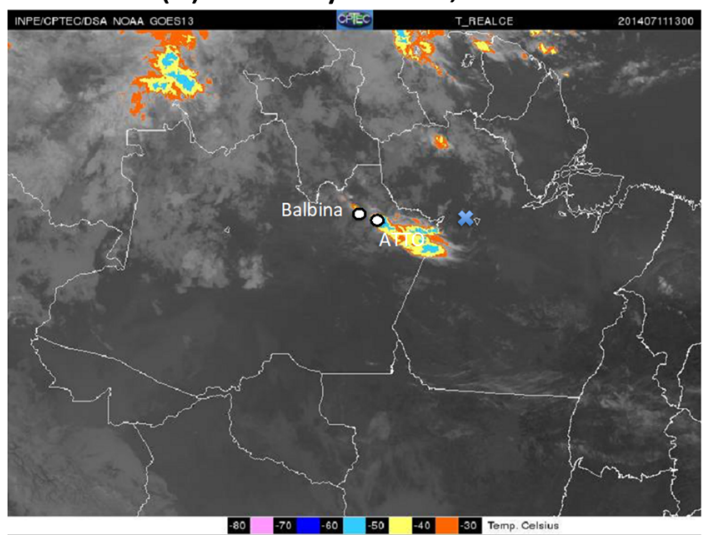

(b) 11 July 2014, 10 UTC

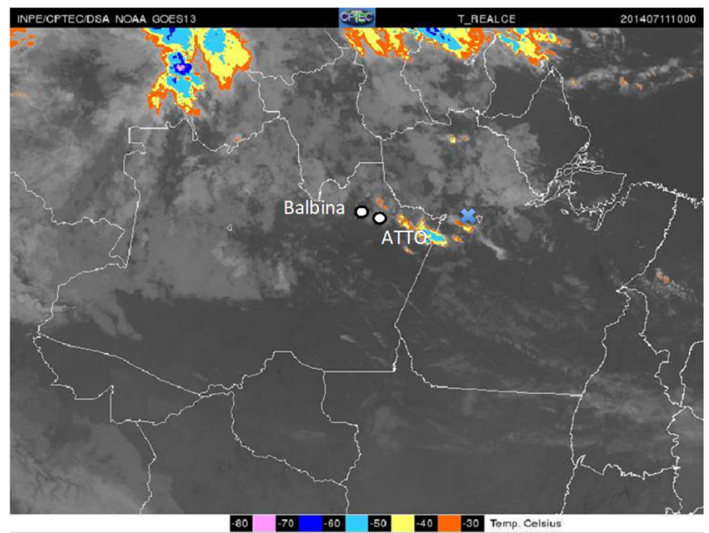

(d) 11 July 2014, 16 UTC

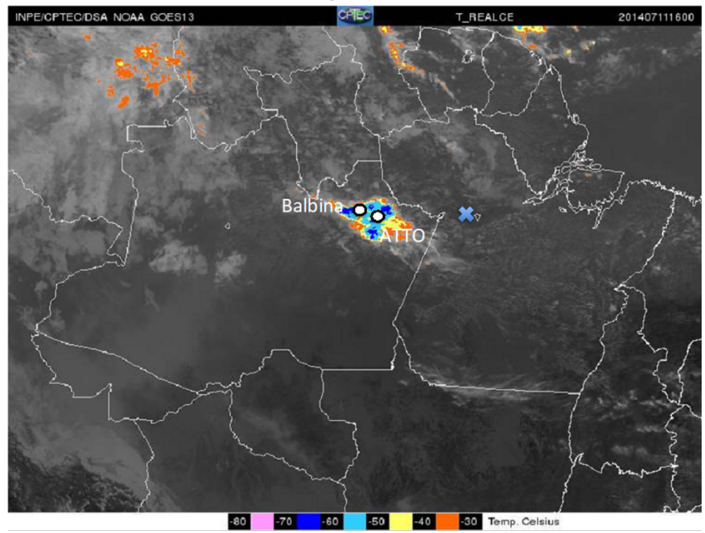

Figure 4. Enhanced images of the GOES 13 satellite in the infrared channel on 11 July 2014 at (a) 07:00 UTC, (b) 10:00 UTC, (c) 13:00 UTC and (d) 16:00 UTC, which is openly accessible (http://satelite.cptec.inpe.br/acervo/goes.formulario.logic?i=br, last access: 7 April 2020), including the approximate locations of the ATTO site and Lake Balbina (white circles) and the confluence region of the Amazon and Tapajós rivers (blue X).

(a) 7 July 2014, 18 UTC

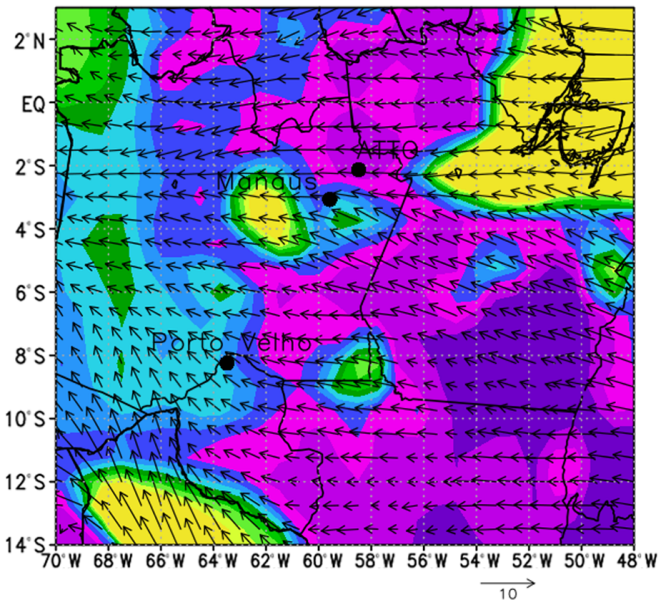

(b) 11 July 2014, 18 UTC

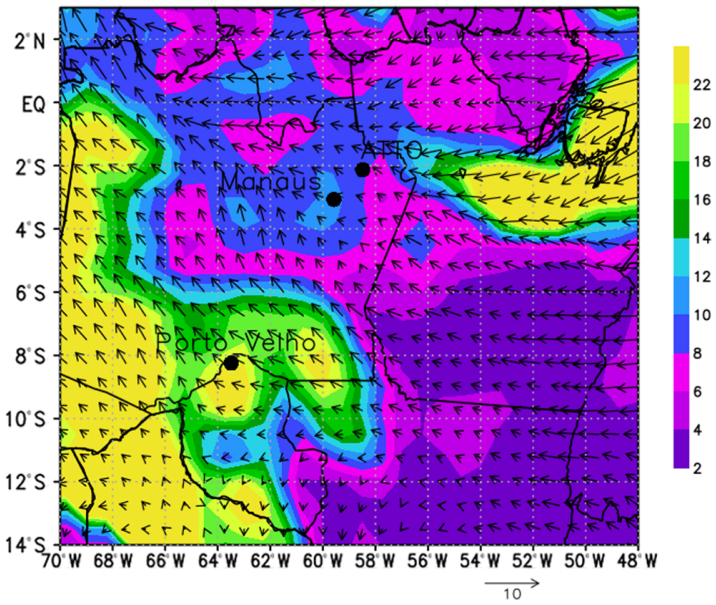

Figure 5. Surface wind ( $\mathrm{m} \mathrm{s}^{-1}$, vectors) and ozone (ppbv, contour) on (a) 7 and (b) 11 July 2014 at 18:00 UTC, highlighting the Porto Velho, Manaus and ATTO sites obtained with the ERA-Interim reanalysis. 


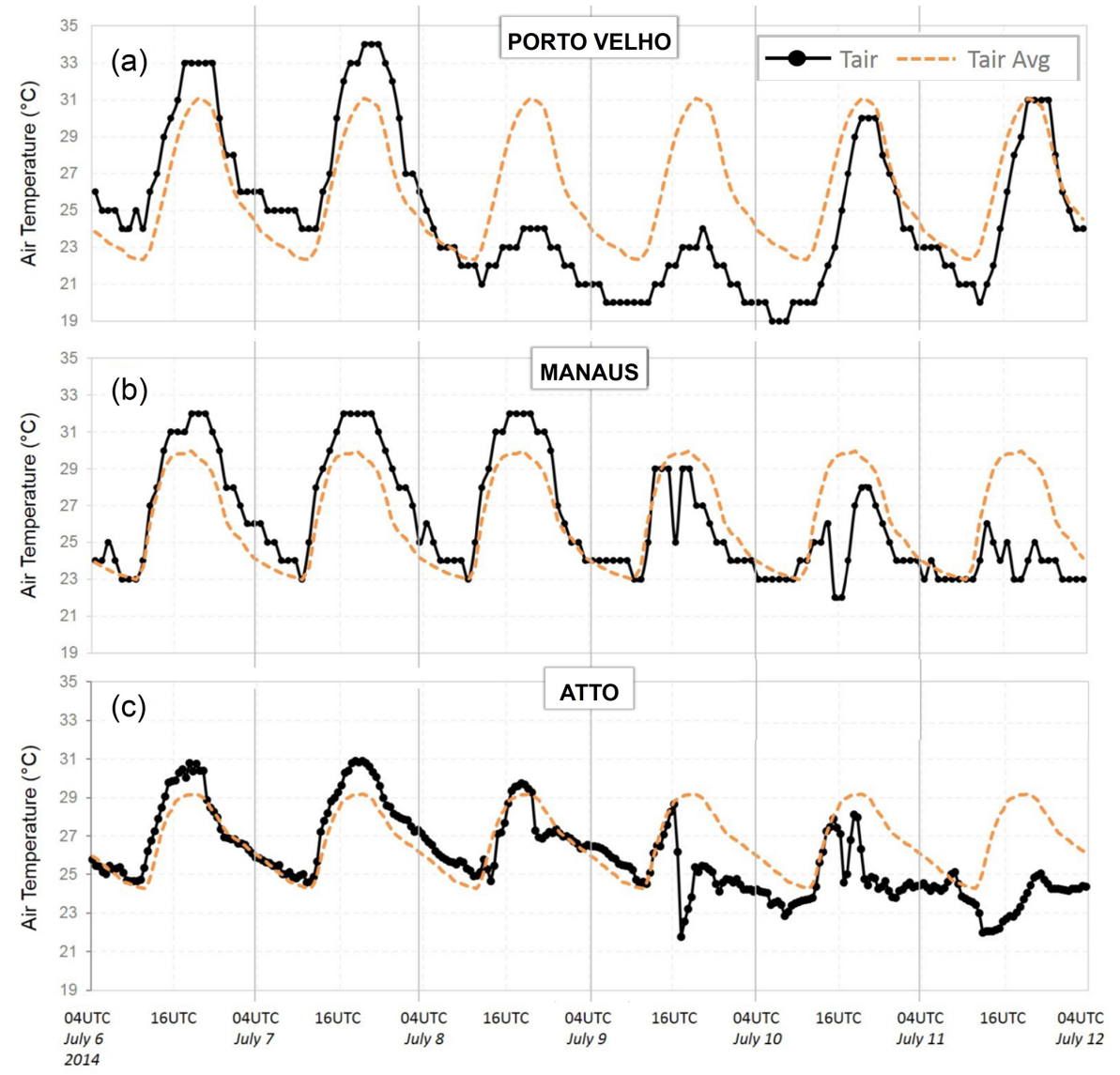

Figure 6. Daily cycle (black line) and monthly average (orange line) of the observational air temperature data from 6 to 11 July 2014 , in (a) Porto Velho, (b) the Manaus region and (c) the ATTO site.

and 10 July. They did not show the impact of friagem on $\mathrm{O}_{3}$ levels but showed that for both events the main consequence of the friagem in the city of Manaus was greater cloud cover and consequently less solar radiation reaching the surface, which was the main cause of the drop in air temperature, corroborating part of the results found here (Figs. 3, 4 and $6)$.

\subsection{Air temperature during the friagem event}

Figure 6 shows the air temperature values near the surface in Porto Velho (Fig. 6a), the Manaus region (Fig. 6b) and above the forest canopy at the ATTO site (Fig. 6c), between 6 and 11 July 2014 (black line), together with the air temperature hourly average for the month of July 2014 (orange line). In Porto Velho, the difference between the maximum mean air temperature (maximum average daily cycle value) and the maximum air temperature during the friagem (8 July) was $7^{\circ} \mathrm{C}$ (from 31 to $24^{\circ} \mathrm{C}$ ), whilst in the Manaus region and at the ATTO site the differences were of the order of $4^{\circ} \mathrm{C}$ (from 30 to 26 and 29 to $25^{\circ} \mathrm{C}$, respectively) during 11 July. The temperature started to fall in the Manaus region and the
ATTO site around $1 \mathrm{~d}$ after the temperature drop observed in Porto Velho.

In Porto Velho, both the maximum and minimum values of air temperature were substantially reduced during the presence of the friagem. However, in the Manaus region and at the ATTO site, the decrease was mainly observed in the maximum temperature values. Although the decrease was not so evident at the time of the diurnal minimum (at least on 10 and 11 July), the whole diurnal cycle was disturbed with (much lower) minima than the average at different times of the day.

Similar behavior was observed by Marengo et al. (1997) for the southwest and central Amazon regions during an episode of the friagem. Therefore, it is noted that due to the occurrence of the friagem, the southernmost regions of the Amazon present more intense reductions in temperature values, compared to the regions located more in the center of the Amazon basin.

Additionally, the ATTO site is located in a forest region, $58 \mathrm{~km}$ from the Balbina Dam lake, and the Manaus region is under the influence of intense urbanization (de Souza and Alvalá, 2014) and is located in the proximity of rivers. Thus, there is evidence that both the ATTO site and Manaus region 
may be under the influence of lake (Moura et al., 2004) and river breezes (dos Santos et al., 2014), respectively, which could offer them greater thermal inertia.

\subsection{ATTO site wind direction}

In addition to the changes observed in the daily air temperature cycle at the ATTO site, changes were also observed in the local wind direction during the friagem period (Fig. 7). Before the arrival of this phenomenon, between 6 and 8 July, it was observed that the directions of the horizontal wind were predominantly southeast and northeast. On the other hand, on 9 July, the wind direction was well distributed among the four cardinal points, and on 10 and 11 July the wind flow had higher frequencies in the west, north and southwest, when the friagem arrived at the ATTO site. The general wind directions before and after the friagem are consistent with long-term observations at the ATTO site (Andreae et al., 2015). The low frequency of observed wind directions from the westerly directions (based on 2.5 years of data) led to the conclusion that effects of local circulation (due to Uatumã River $\approx 12 \mathrm{~km}$ and Lake Balbina $\approx 58 \mathrm{~km}$ ) are not important or could not be observed (Andreae et al., 2015), at least not on a regular basis.

Silva Dias et al. (2004) showed that during the period from 24 to 31 July 2001, there was an arrival of a cold air mass in the western region of the Amazon. The main consequences of this friagem in the region were increased atmospheric pressure to the sea level, a decrease in air temperature around $5^{\circ} \mathrm{C}$, a reduction in wind speed and confluence of a cold and dry air mass coming from the southern region with a hot and humid air mass coming eastern Amazon. We emphasize that part of our results are corroborated by Silva Dias et al. (2004). The increased atmospheric pressure to sea level resulted in a pressure gradient force pointing in the opposite direction from the trade winds, which would be consistent with a slowdown of the easterly winds. In this way, these authors were able to observe with greater clarity the occurrence of river breeze circulations in this region. Following this hypothesis, the behavior of the wind at the ATTO site was analyzed every $2 \mathrm{~h}$, during the period in which the friagem was active in this region (Fig. 8).

On 9 July, it is observed that the direction of the wind was essentially from the east until the end of the morning (14:00-16:00 UTC), when the wind changed to southeast and southwest directions until the late afternoon and early evening (22:00-00:00 UTC), which corresponds to the flow associated with the arrival of friagem in this region. From 00:00 UTC to 14:00 UTC on 10 July, it is observed that the prevailing wind was from the west, indicating a deviation from the general flow, which would normally be from the east. In the early afternoon (16:00 UTC), the wind changed to the north direction until the early morning (12:00 UTC) of 11 July. This change in wind direction to the west and to the north observed during the mornings of 10 and 11 July, respectively, does not correspond to the expected direction during the occurrence of the forest breeze towards Lake Balbina, which should be from east to southeast. Therefore, it is believed that the flow related to the friagem phenomenon overlapped with that of the breeze circulation observed by Moura et al. (2004), or that the forest-lake breeze circulation does not present the capacity to reach the micrometeorological tower of the ATTO site in $58 \mathrm{~km}$ distance (in line with results from Andreae et al., 2015). This aspect will be discussed in the next section where the results of the simulation with JULES-CCATT-BRAMS model will be analyzed.

\subsection{Radiation, ozone and $\mathrm{CO}_{2}$ during the friagem event}

Figure 9 shows the values of incident shortwave radiation $\left(\mathrm{SW}_{\text {in }}\right), \mathrm{O}_{3}$ and $\mathrm{CO}_{2}$ measured at the ATTO site, between 6 and 11 July 2014, respectively (black line). The $\mathrm{SW}_{\text {in }}$ values decrease during the morning of 11 July when the friagem arrives at the ATTO site (Fig. 9a). Moreover, the maximum value $\left(\approx 450 \mathrm{~W} \mathrm{~m}^{-2}\right)$ of $\mathrm{SW}_{\text {in }}$ occurred at approximately 19:00 UTC (15:00 LT), whereas the average monthly daily maximum $\mathrm{SW}_{\text {in }}$ (orange line) usually occurs at 16:00 UTC $\left(\approx 800 \mathrm{~W} \mathrm{~m}^{-2}\right)$.

Before the arrival of the friagem in the region of the ATTO site, between 6 and $8 \mathrm{July}$, it was observed that the values of $\mathrm{O}_{3}$ (black line) were close to the monthly average (orange line), with minimum values occurring around 10:00 UTC (06:00 LT) and maximum around 17:00 UTC (Fig. 9b). This result is consistent with those observed in other studies conducted in the Amazon (Betts et al., 2002; Gerken et al., 2016; Dias-Júnior et al., 2017; Melo et al., 2019). However, during the occurrence of the friagem, between 9 and 11 July, there was a sharp drop in $\mathrm{O}_{3}$ mixing ratio at the times when the highest mixing ratios of this trace gas were expected (17:00 UTC).

Figure 10 shows the $\mathrm{O}_{3}$ mixing ratio data from four different stations around the city of Manaus. All stations show reduced $\mathrm{O}_{3}$ values during the passage of the friagem event (dotted black rectangle). Furthermore, stations affected directly by the pollution of the city of Manaus (Iranduba - T2, Manacapuru - T3) show a clear influence of increased $\mathrm{O}_{3}$ formation compared to ATTO and ZF2-T0z. These differences are much smaller during the friagem event, probably due to reduced photochemistry (Fig. 9a) in this region.

The reduction of the incident shortwave radiation values observed on 11 July (Fig. 9a) was possibly associated with the presence of convective systems in this region, as shown in Fig. 4. It is known that cloudiness is a determinant meteorological factor in the daily $\mathrm{O}_{3}$ cycle (Gerken et al., 2016).

It is interesting to note that the rain event during 11 July did not result in an increase of near-surface $\mathrm{O}_{3}$ as observed by others authors (Betts et al., 2002; Gerken et al., 2016; Dias-Júnior et al., 2017). It is believed that the convective cloud formed during the friagem event was not as deep as the clouds investigated by Betts et al. (2002) and Gerken et al. 

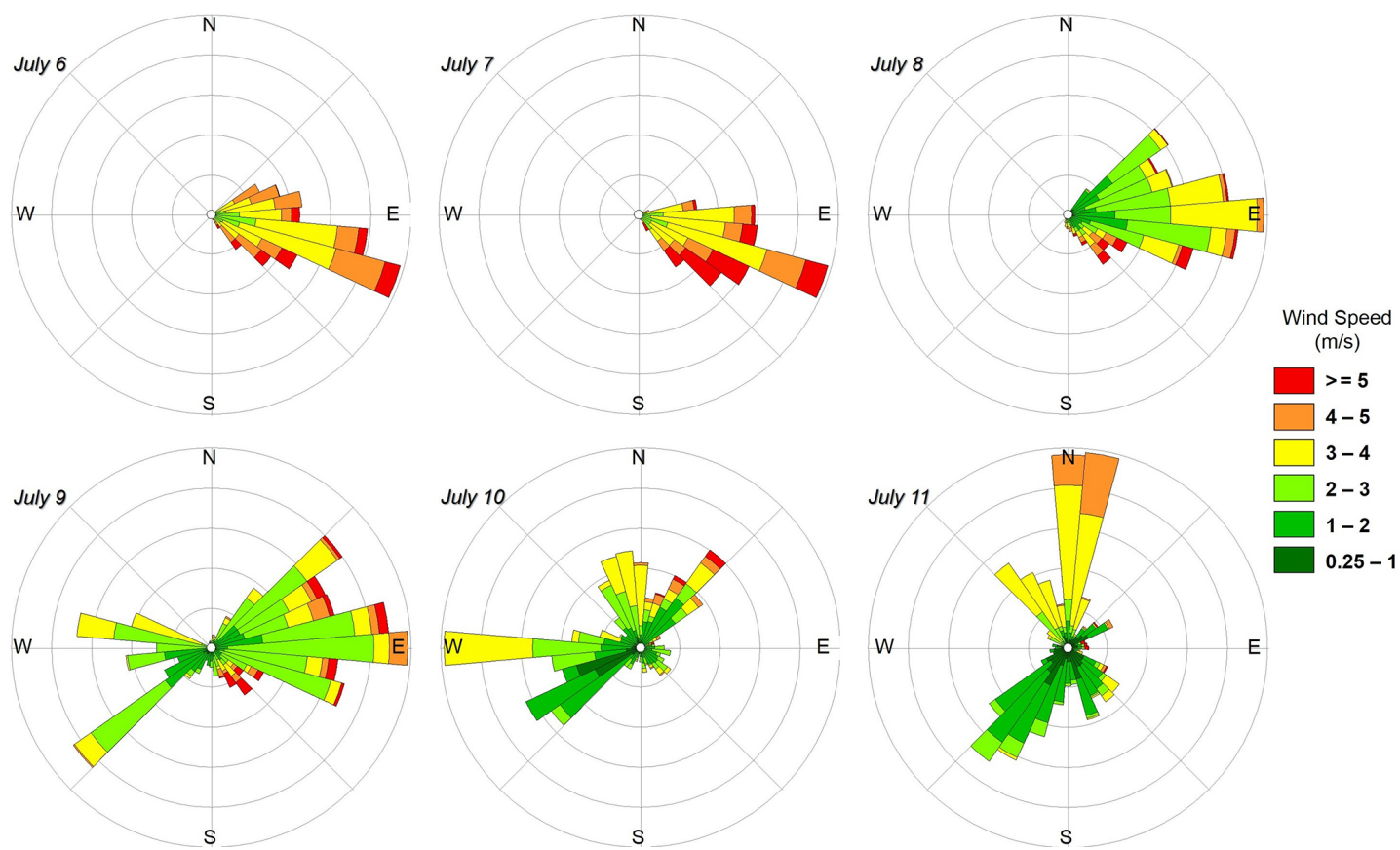

Figure 7. Experimental horizontal wind speed and direction at $73 \mathrm{~m}$ above ground measured at the ATTO site between 6 and 11 July 2014 .

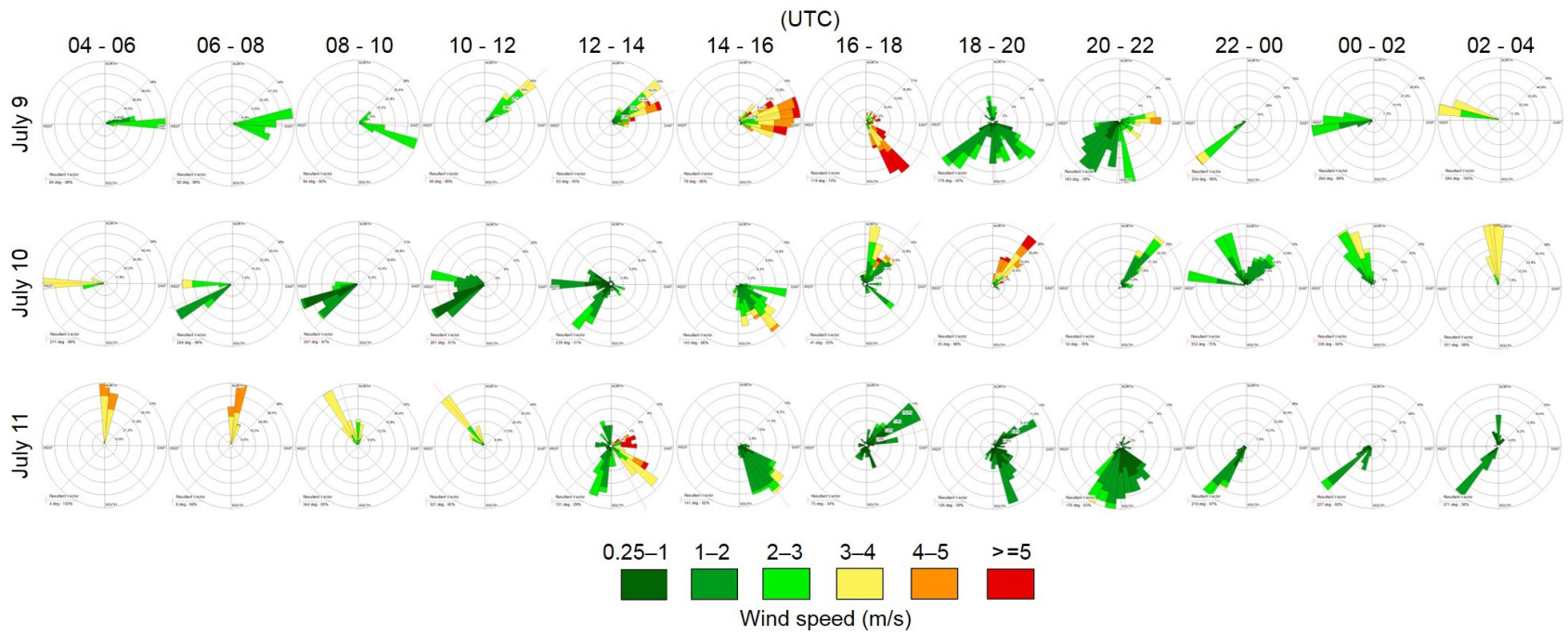

Figure 8. Experimental wind speed and direction at the $73 \mathrm{~m}$ above ground measured at the ATTO site, in $2 \mathrm{~h}$ intervals, between 9 and $11 \mathrm{July}$ 2014.

(2016), which, through their downdrafts, transport $\mathrm{O}_{3}$ from the high troposphere to the surface.

The values of $\mathrm{CO}_{2}$ mixing ratio between 6 and 11 July are shown in Fig. 9c. It is observed that between 6 and 10 July, $\mathrm{CO}_{2}$ values for the daily cycle (black line) were very close to the monthly average values (orange line), with a maximum molar fraction around $420 \mathrm{ppm}$ approximately at 10:00 UTC and minimum of less than $390 \mathrm{ppm}$ (de Araújo et al., 2010). However, on 11 July at 14:00 UTC, a significant increase of $\mathrm{CO}_{2}(\approx 470 \mathrm{ppm})$ was observed in relation to the monthly average. This increase may be related to the incident radiation attenuation due to increased cloudiness which reduces the efficiency of the forest in absorbing $\mathrm{CO}_{2}$ gas via photosynthesis (Ruimy et al., 1995). Also limited vertical mixing as discussed below is a potential reason. 

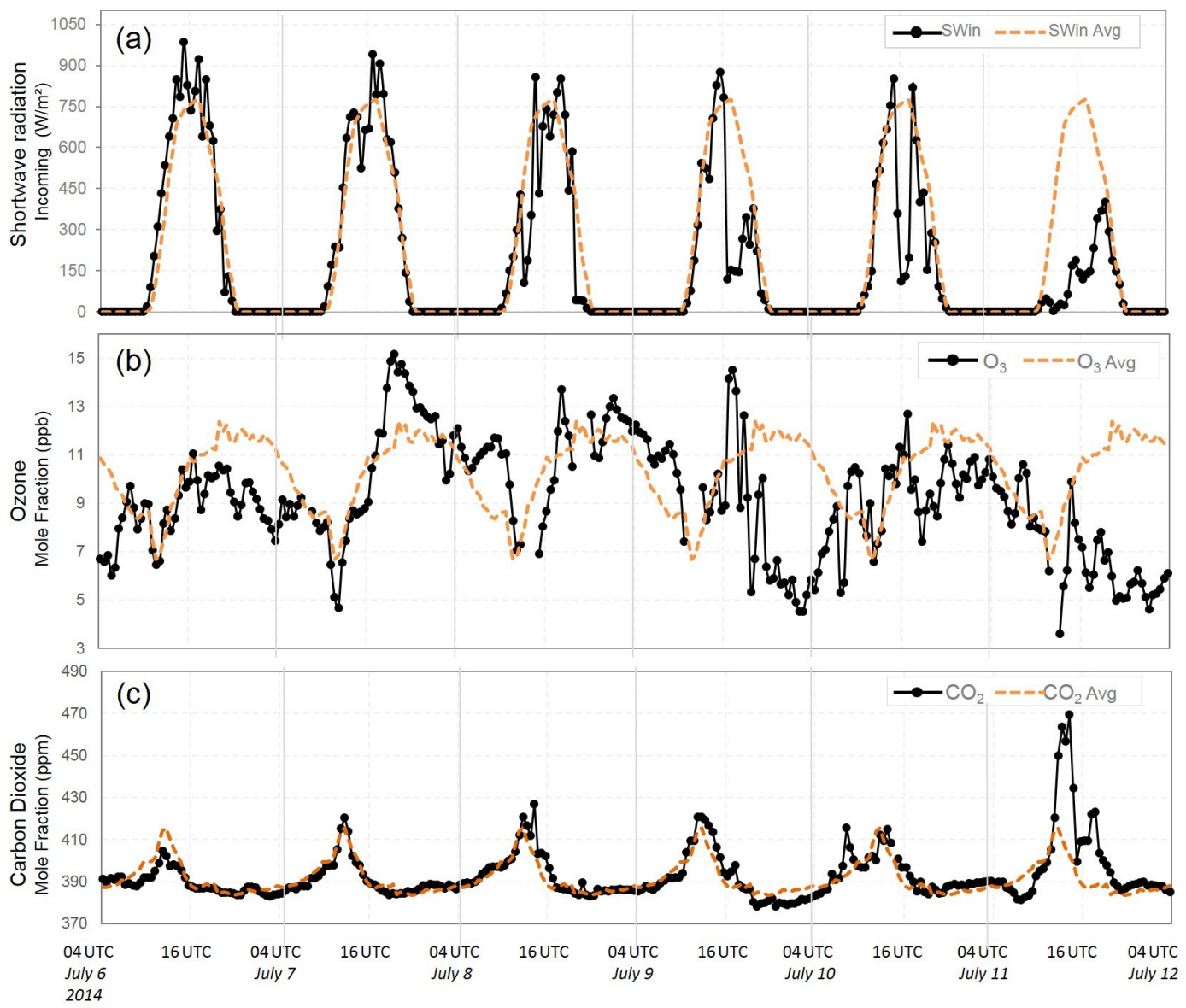

Figure 9. Daily behavior (black line) and monthly average (orange line) of the experimental data: (a) incident shortwave radiation ( $\mathrm{SW}_{\text {in }}$ ), (b) ozone $\left(\mathrm{O}_{3}\right)$ and (c) carbon dioxide $\left(\mathrm{CO}_{2}\right)$ mixing ratio from 6 to 11 July 2014 at the ATTO site.

\subsection{Simulation of local circulation and its effect at the ATTO site}

In order to better understand the local circulation and its role in the measurements made in the region of the ATTO site, this section presents the results of a numerical simulation made with the JULES-CCATT-BRAMS coupled model. Figure 11a shows the vertical profile of the horizontal wind at a grid point near the ATTO site $\left(2^{\circ} \mathrm{S}, 59^{\circ} \mathrm{W}\right)$ during model integration. At low levels (near $80 \mathrm{~m}$ ), the easterly wind is observed until the first hours of 10 July. Then the wind has a predominant west-northwest direction until the afternoon of $11 \mathrm{July}$, and afterwards the wind comes from the south. Therefore, it is observed that the simulation captured the horizontal wind behavior measured at a height of $73 \mathrm{~m}$ at the ATTO site, as shown in Fig. 8. In addition, above $500 \mathrm{~m}$, the flow is essentially from the east during the whole period of integration of the model. Apparently, the friagem only changes the flow within a small layer adjunct to the ground. Figure 11b shows the values of the boundary layer height (BLH) obtained from ERA5 at a grid point near the ATTO site $\left(2.10^{\circ} \mathrm{S}, 59.06^{\circ} \mathrm{W}\right)$. It is possible to note that before the friagem event the maximum BLH values were greater than $1000 \mathrm{~m}$. However, during the friagem event, the maximum BLH value was around $600 \mathrm{~m}$.

The large temperature drop (Fig. 6a), together with the information that the cold air of the friagem was just in the lower $500 \mathrm{~m}$ (Fig. 11), points to the formation of a cold pool above the forest that prevents vertical mixing. As incoming solar radiation was low (Fig. 9a), the surface heating might not be sufficient to break the inversion or at least a very shallow boundary layer was formed as evidenced by the ERA5 data (Fig.11b). This would explain high $\mathrm{CO}_{2}$ (accumulation of soil emissions) and very low $\mathrm{O}_{3}$ (limited transport from aloft) at the same time at the ATTO site in addition to the reduced radiation (see Sect. 3.3).

Figure 12 shows the evolution of the temperature at $76.8 \mathrm{~m}$ $\left({ }^{\circ} \mathrm{C}\right.$, shaded) and horizontal wind $\left(\mathrm{m} \mathrm{s}^{-1}\right.$, vector $)$ at $134.5 \mathrm{~m}$ on 11 July. Between 03:00 and 11:00 UTC, the air temperature is higher on Lake Balbina compared to that above the forest area. This temperature gradient induces the formation of a forest breeze towards the lake with the wind converging towards the center of the lake (Fig. 12a-e). At 13:00 UTC, the temperature gradient reverses its direction and induces 


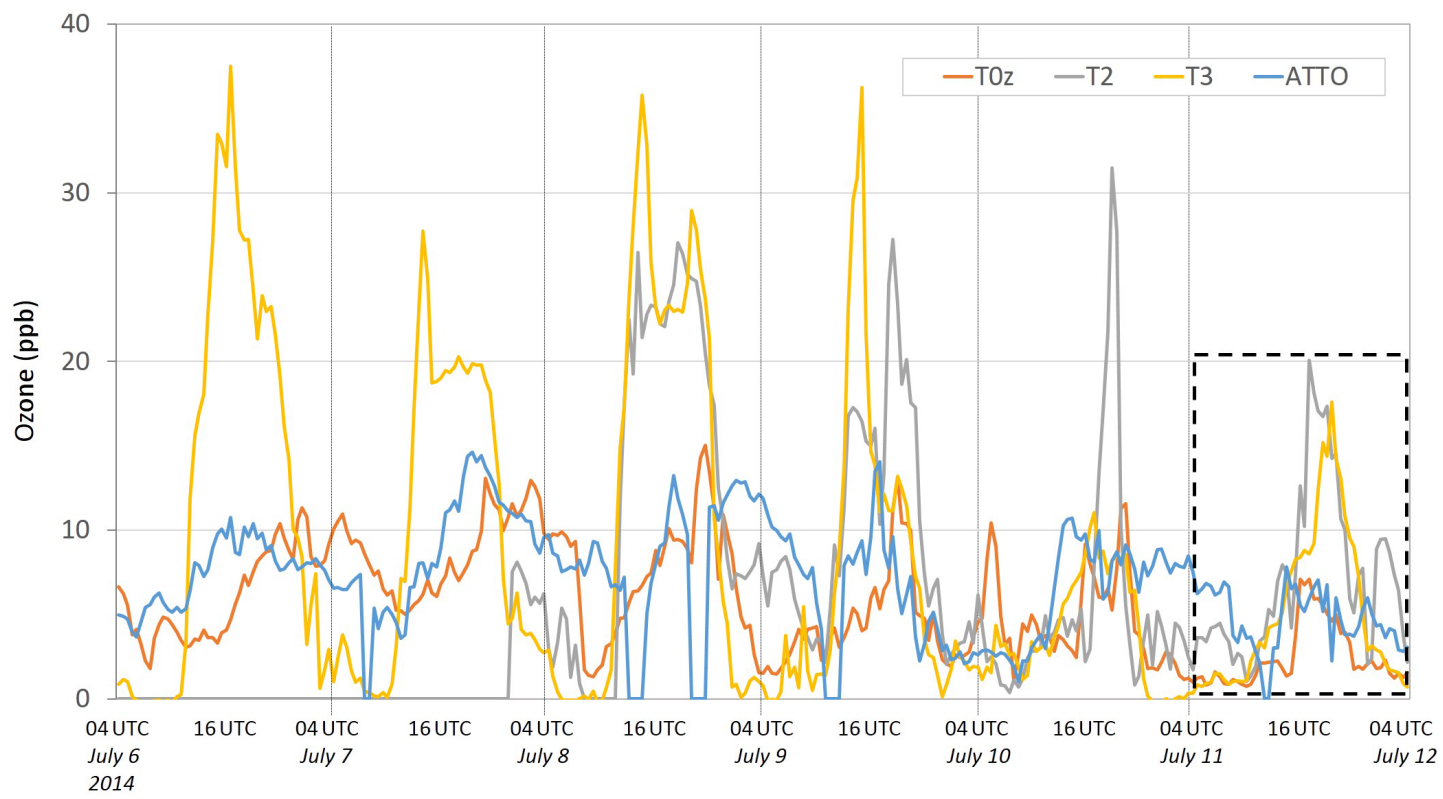

Figure 10. $\mathrm{O}_{3}$ mixing ratio (ppbv) from four different stations around Manaus: the ATTO site (blue line), ZF2 forest - T0z (red line), Iranduba - T2 (grey line), Manacapuru - T3 (yellow line). The black rectangle indicates the occurrence of the friagem event. T2 is affected directly by the polluted air from the city of Manaus.

(a)

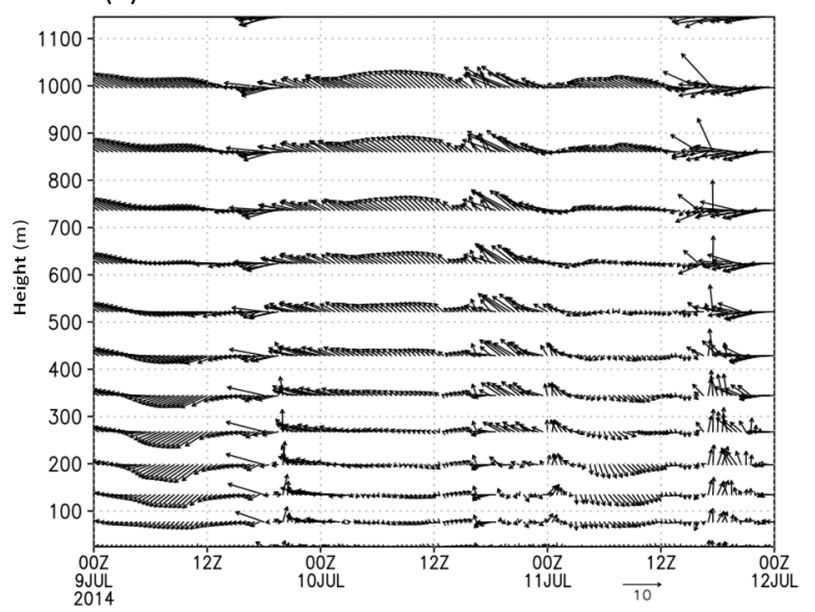

(b)

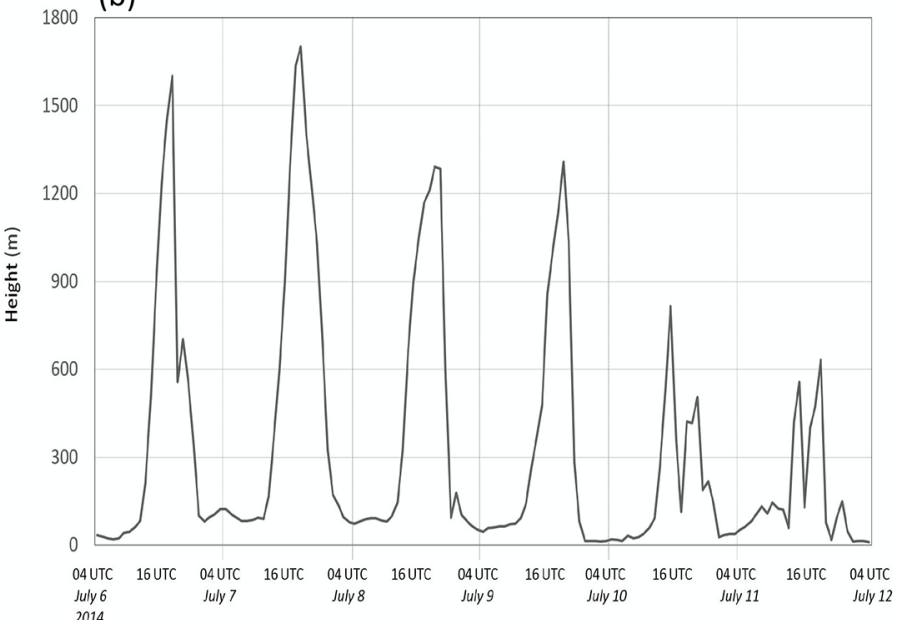

Figure 11. (a) Vertical profile of the horizontal wind $\left(\mathrm{m} \mathrm{s}^{-1}\right)$ obtained by the JULES-CCATT-BRAMS simulation for the ATTO site from 00:00 UTC on 9 July to 00:00 UTC on 12 July 2014. (b) Boundary layer height (m) obtained from ERA5 for the ATTO site from 04:00 UTC on 6 July to 04:00 UTC on 12 July 2014.

the formation of the lake breeze towards the forest that at 15:00 UTC is more clearly defined along the southeastern shores of Lake Balbina (Fig. 12g).

Another interesting aspect is the entry of cooler air through the northwest quadrant starting at 03:00 UTC, which is transported in the southeast direction. From 03:00 to 11:00 UTC, a corridor of warmer air is established from Lake Balbina to the southeast quadrant of the domain along the Uatumã River, whose width is less than $1 \mathrm{~km}$ and cannot be captured by the horizontal resolution in this simulation. The gradual drop in temperature and predominance of northwest winds shown in this simulation at the grid points near the ATTO site agree with the observational data from this site (Figs. 6 and 7).

Although the Lake Balbina breeze was established, it did not reach the ATTO site until 15:00 UTC (Fig. 12g). In addition, precipitation in the simulation occurred in the following hours, similar to that observed in satellite images 
(a)Temperature 11 July, 03 UTC

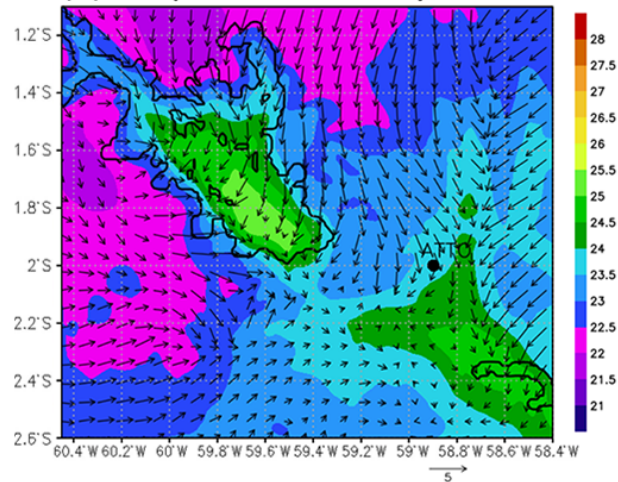

(c)Temperature 11 July, 07 UTC

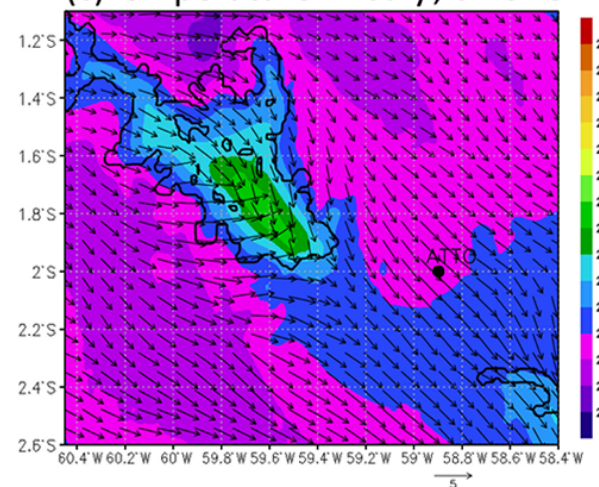

(e)Temperature 11 July, 11 UTC

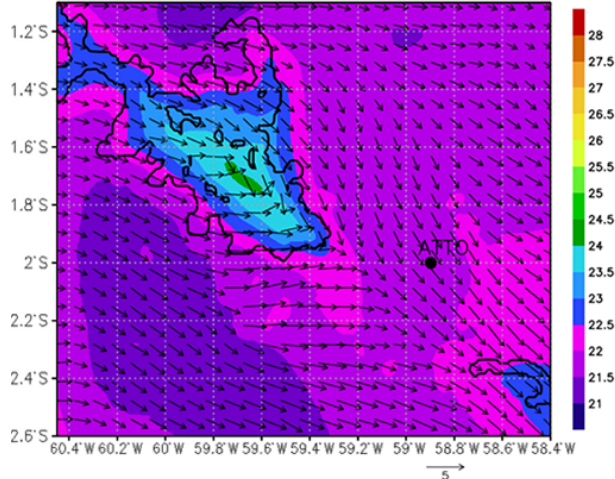

(g)Temperature 11 July, 15 UTC

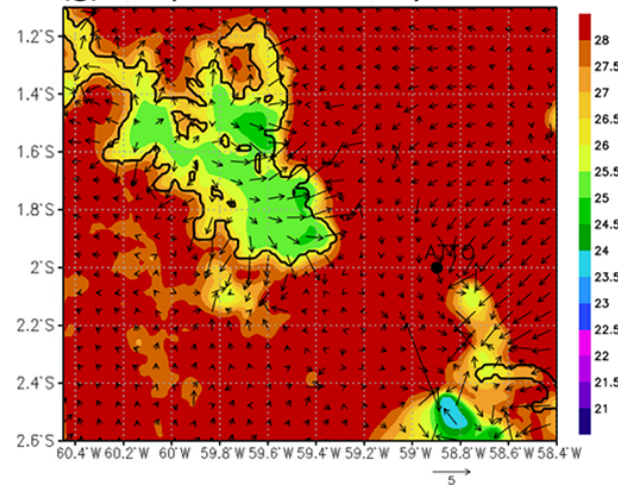

(b)Temperature 11 July, 05 UTC

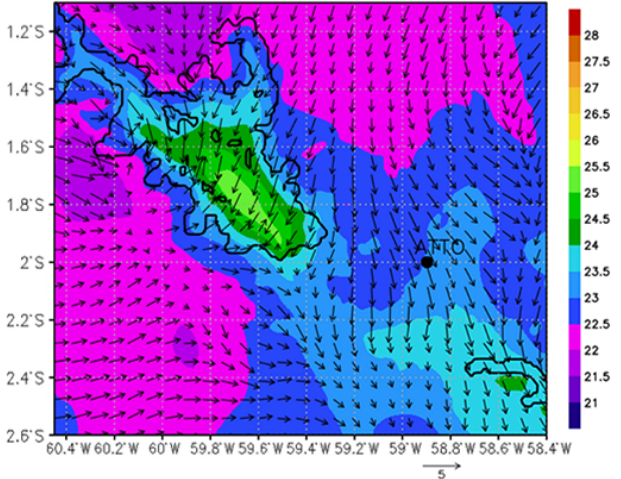

(d)Temperature 11 July, 09 UTC

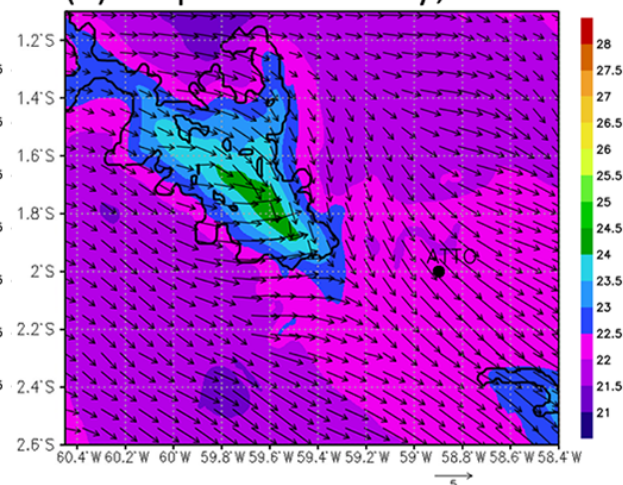

(f)Temperature 11 July, 13 UTC

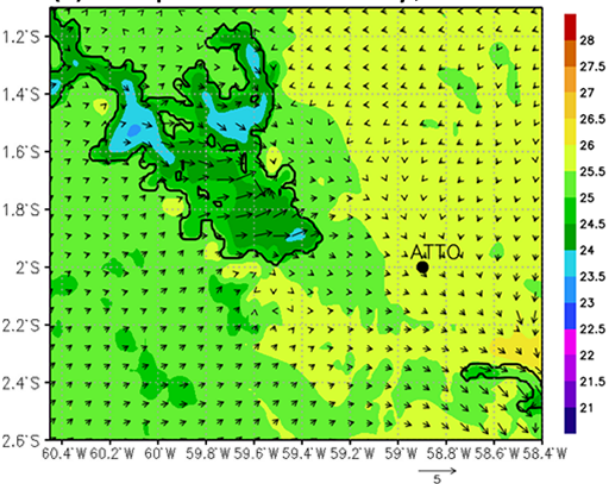

(h)Temperature 11 July, 17 UTC

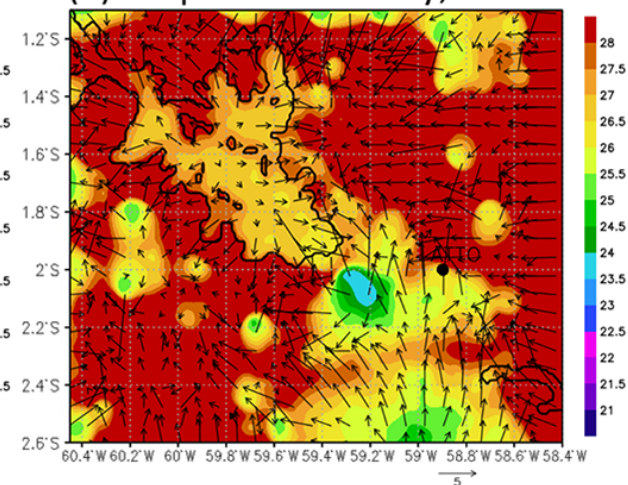

Figure 12. Evolution of modeled air temperature $\left({ }^{\circ} \mathrm{C}\right.$, shaded) at $76.8 \mathrm{~m}$ and horizontal wind ( $\mathrm{m} \mathrm{s}^{-1}$, vector) at $134.5 \mathrm{~m}$, on $11 \mathrm{July} 2014$ at (a) 03:00 UTC, (b) 05:00 UTC, (c) 07:00 UTC, (d) 09:00 UTC, (e) 11:00 UTC, (f) 13:00 UTC, (g) 15:00 UTC and (h) 17:00 UTC. Lake Balbina (black contour) and the ATTO site (black dot) are indicated. 
(a) Water Vapor 11 July, 02 UTC

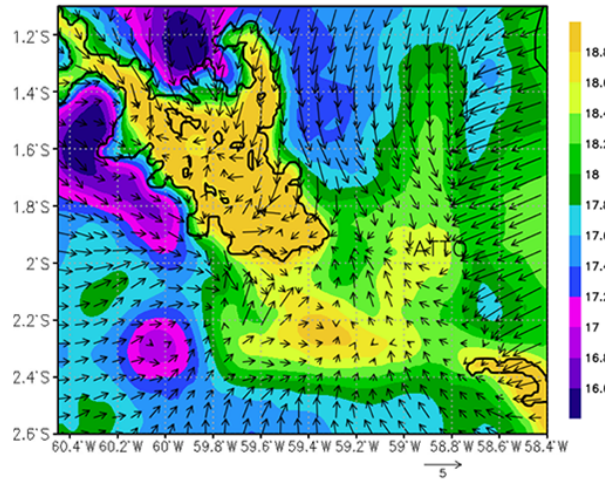

(c) Ozone 11 July, 02 UTC

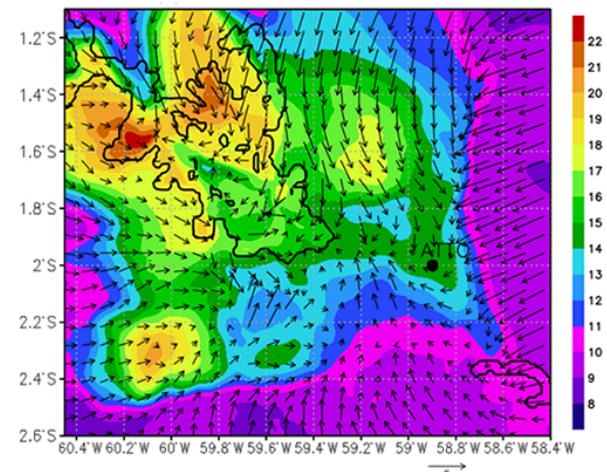

(e) Carbon Monoxide 11 July, 02 UTC

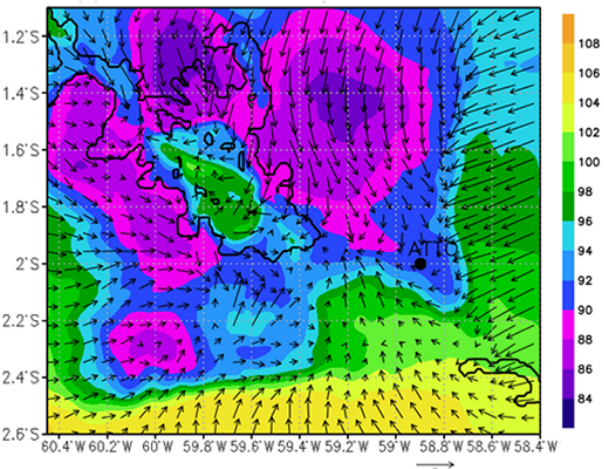

(g) Nitrogen dioxide 11 July, 02 UTC

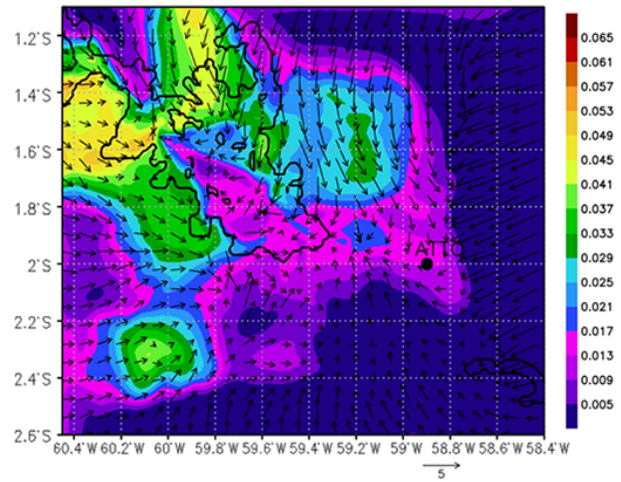

(b) Water Vapor 11 July, 12 UTC

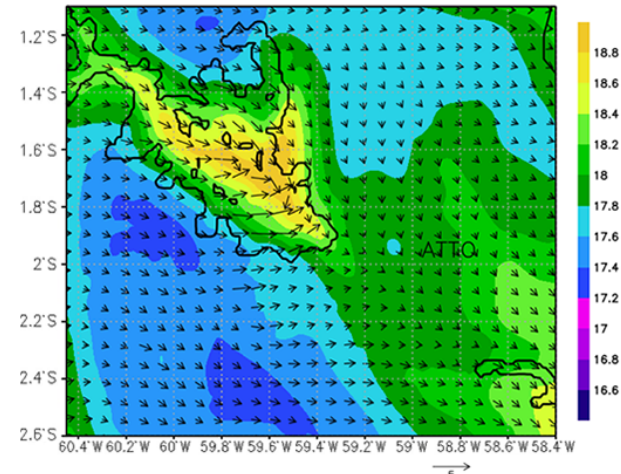

(d) Ozone July 11, 12 UTC

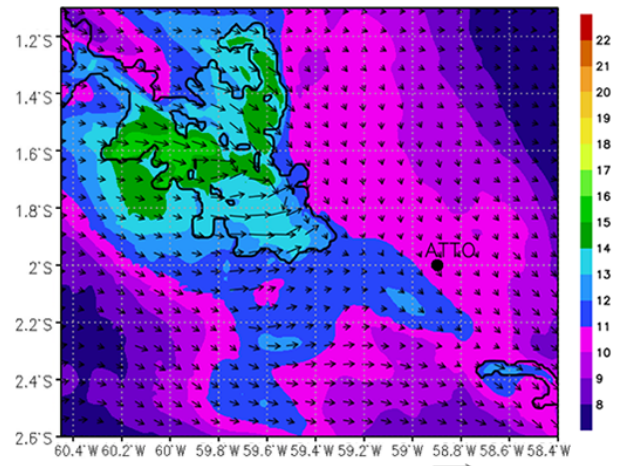

(f) Carbon Monoxide 11 July, 12 UTC

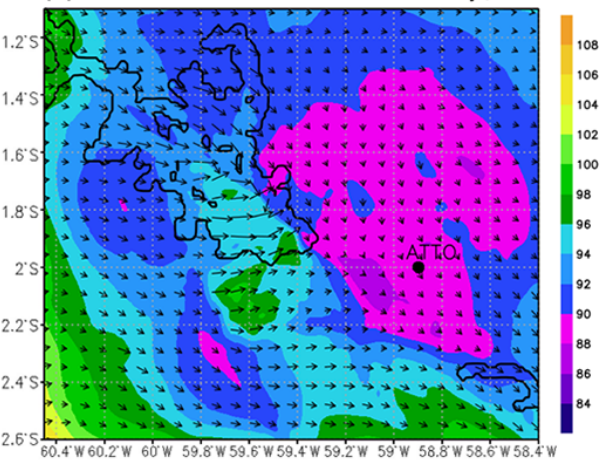

(h) Nitrogen dioxide 11 July, 12 UTC

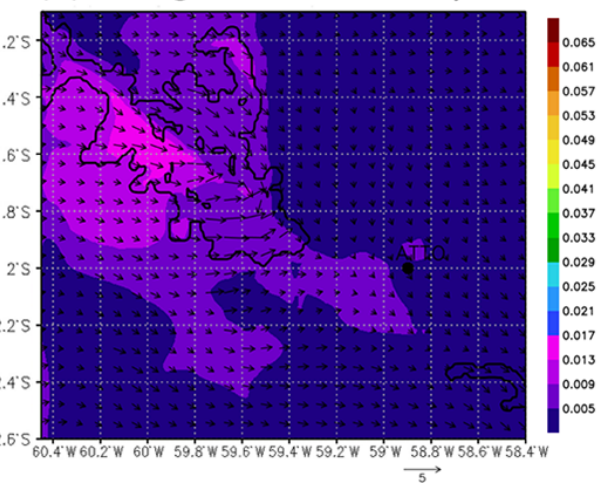

Figure 13. Simulated horizontal wind at $134.5 \mathrm{~m}$ on 11 July 2014 for the (a, b) water vapor mixture ratio $\left(\mathrm{g} \mathrm{kg}^{-1}, \mathrm{shaded}^{\mathrm{d}}\right.$, (c, d) ozone mixing ratio (ppbv, shaded), (e, f) carbon monoxide mixing ratio (ppbv, shaded) and (g, h) nitrogen dioxide mixing ratio (ppbv, shaded) at $24.4 \mathrm{~m}$, when the friagem arrived at the study area (a, $, \mathbf{e}, \mathbf{e}, \mathbf{g})$ and at the moment of its dissipation (b, $\mathbf{d}, \mathbf{f}, \mathbf{g})$. Lake Balbina (black outline) and the ATTO site (black dot) are indicated. 
(Fig. 4), which in turn disrupts the environment propitious to vigorous breezes that could reach the ATTO site. Although the friagem phenomenon causes the weakening of the trade winds, which in turn would allow the establishment of more intense breezes as proposed by Silva Dias et al. (2004), the cooler and drier air mass flow of the friagem in the central region of the Amazon was dominant over the lake and forest breeze circulation. Possibly, the establishment of more vigorous river breeze circulations observed by Silva Dias et al. (2004) is possible due to the friagem phenomenon not reaching that region and interfering with the signal of the breeze and causing intense rainfall.

Figure 13 shows the behavior of modeled water vapor, $\mathrm{O}_{3}$, $\mathrm{CO}$ and $\mathrm{NO}_{2}$ on 11 July 2014 at the moment of incursion (Fig. 13a, c, f, g) and dissipation (Fig. 13b, d, f, h) of the friagem in the study area. The mixing ratios of water vapor near the surface at 02:00 UTC (Fig. 13a) were lower in the regions where cooler air was observed entering this domain, indicating that the friagem brought cold and dry air to the ATTO site and Lake Balbina.

$\mathrm{O}_{3}$ mixing ratios are higher above the lake and its surroundings, for both times shown (Fig. 13c and d). The $\mathrm{O}_{3}$ mixing ratios within the limits of the simulation domain are mostly below $11 \mathrm{ppbv}$, whereas above the lake these mixing ratios exceed $20 \mathrm{ppbv}$ at certain points, especially at 02:00 UTC. The effect responsible for higher $\mathrm{O}_{3}$ mixing ratios both during the day and at night may be associated with the fact that deposition is very much reduced over the open water compared to the forest (Ganzeveld et al., 2009). It can also be seen that the friagem extended in the direction of the ATTO site but probably due to the onset of rain (Fig. 4) was not clearly detected at the ATTO site.

In terms of $\mathrm{CO}$ gas, it can be observed that its concentration at the center of the lake at 02:00 UTC (Fig. 13e) is higher than in the regions near the margins of the lake; however, this calls attention at this time to the transport of $\mathrm{CO}$ arriving with the south and northeast winds, approaching the ATTO site. However, it is noted that the entire region of the simulation domain presents low $\mathrm{CO}$ mixing ratios at the time the friagem is dissipated (Fig. 13f). Apparently, the friagem event "expels" the polluted air mass in the south and southeast of the ATTO site (around Manaus city), "cleaning" the atmosphere or preventing this pollution from reaching the ATTO site and Lake Balbina.

$\mathrm{NO}_{2}$ gas is an important precursor of $\mathrm{O}_{3}$ and is mainly related to emissions from fires and vehicles. The emission of precursor gases in the formation of $\mathrm{O}_{3}$ mixing ratio of this trace gas can increase to levels harmful to the forest, since the ozone can damage the stomatal functions of the leaves (Pacifico et al., 2015). In spite of this, it is observed that the higher $\mathrm{NO}_{2}$ mixing ratios at 02:00 UTC (Fig. 13g) seem to have their origin in the region where higher $\mathrm{O}_{3}$ mixing ratios are found and presented lower $\mathrm{NO}_{2}$ during the time of dissipation of the friagem (Fig. 13h).

\section{Conclusion}

In the period of 9 to 11 July 2014, a friagem phenomenon reached the central region of the Amazon. Through the ECMWF ERA-Interim reanalysis it was possible to verify that this phenomenon ventured into the Amazon region from southwest to northeast, bringing a strong, cold, dry, ozonerich air mass in the western quadrant, which dominated the wind field in the central region of the Amazon.

Through the observational data, it was possible to verify that the passage of the friagem in the central Amazon had its most significant effects on $11 \mathrm{July}$, in the region of the city of Manaus, such as Lake Balbina, the ATTO site and others sites (T2, T3 and T0z).

From the observational data collected at the ATTO site, it was observed that 11 July was marked by a sudden drop in air temperature, a weakening of the typical eastern flow and a predominance of south, west and north winds. In addition, on 11 July, the interaction between the friagem air mass and the trade winds flow gave origin to convection bands, which in turn caused a significant reduction of the incident shortwave radiation, besides a record rain of the month. With the BRAMS simulations we found that the cold air of the friagem was just in the lower $500 \mathrm{~m}$. This information leads us to the conclusion that there is a cold pool above the forest that prevents vertical mixing and consequently contributes to an increase in $\mathrm{CO}_{2}$ mixing ratio and abrupt drop in $\mathrm{O}_{3}$ mixing ratio above the forest canopy.

Also, through the simulations of the JULES-CCATTBRAMS it was possible to evaluate the main impacts that the friagem phenomenon caused both in the thermodynamic characteristics and in the atmospheric chemistry of the central region of the Amazon. In addition, the breeze circulations between Lake Balbina and the forest were well represented in the simulations; however, it was not possible to verify the influence of this breeze in trace gas concentrations at the ATTO site.

With the observational results and the simulations, it can be concluded that the friagem phenomenon can interfere deeply in the microclimatic conditions and the chemical composition of the atmosphere, in a region of dense forest, in the center of the Amazon.

Data availability. The ATTO data used in these study are stored in the ATTO databases at the Max Planck Institute for Chemistry and the Instituto Nacional de Pesquisas da Amazônia. Data access can be requested from Stefan Wolff, who maintains the $\mathrm{O}_{3}$ mixing ratio dataset (stefan.wolff@mpic.de), and Alessandro Araújo, who maintains the micrometeorology dataset (alessandro.araujo@gmail.com). The GoAmazon data used in these study can be requested from Luciana Rizzo (luvarizzo@gmail.com).

Author contributions. GFCN, JCPC and CQDJ designed the study and wrote the article with the assistance of MS and JHC. SW, RAFS 
and PA maintained the greenhouse gas measurement system at the ATTO site and provided the $\mathrm{CO}_{2}$ and $\mathrm{O}_{3}$ data. AA and MS operated and maintained the micrometeorology equipment at ATTO and provided the data which were fundamental for this study. LVR provided the $\mathrm{O}_{3}$ data from GoAmazon sites. PAFK and JCPC assisted with BRAMS simulations.

Competing interests. The authors declare that they have no conflict of interest.

Special issue statement. This article is part of the special issue "Amazon Tall Tower Observatory (ATTO) Special Issue". It is not associated with a conference.

Acknowledgements. This work has been supported by the Max Planck Society as well as the Amazon State University (UEA), FAPEAM, LBA/INPA and SDS/CEUC/RDS-Uatumã. We also thank the European Centre for Medium-Range Weather Forecasts (ECMWF) for the reanalysis data and the Center for Weather Prediction and Climate Studies (Centro de Previsão do Tempo e Estudos Climáticos (CPTEC/INPE)) for providing the JULESCCATT-BRAMS model. Furthermore, the authors thank the Amazon Modeling Laboratory (Laboratório de Modelagem da Amazônia, LAMAZ) for the technical help given and also the Brazilian Research Council (CNPq, Conselho Nacional de Desenvolvimento Científico e Tecnológico) for the Masters scholarship. ERA5 data are courtesy of Benedikt Steil.

Financial support. This research has been supported by the German Federal Ministry of Education and Research (BMBF contract nos. 01LB1001A and 01LK1602B) and the Brazilian Ministério da Ciência, Tecnologia e Inovação (MCTI/FINEP contract no. 01.11.01248.00).

Review statement. This paper was edited by Gilberto Fisch and reviewed by two anonymous referees.

\section{References}

Alcântara, C. R., Dias, M. A. S., Souza, E. P., and Cohen, J. C.: Verification of the role of the low level jets in Amazon squall lines, Atmos. Res., 100, 36-44, https://doi.org/10.1016/j.atmosres.2010.12.023, 2011.

Andreae, M. O., Acevedo, O. C., Araùjo, A., Artaxo, P., Barbosa, C. G. G., Barbosa, H. M. J., Brito, J., Carbone, S., Chi, X., Cintra, B. B. L., da Silva, N. F., Dias, N. L., Dias-Júnior, C. Q., Ditas, F., Ditz, R., Godoi, A. F. L., Godoi, R. H. M., Heimann, M., Hoffmann, T., Kesselmeier, J., Könemann, T., Krüger, M. L., Lavric, J. V., Manzi, A. O., Lopes, A. P., Martins, D. L., Mikhailov, E. F., Moran-Zuloaga, D., Nelson, B. W., Nölscher, A. C., Santos Nogueira, D., Piedade, M. T. F., Pöhlker, C., Pöschl, U., Quesada, C. A., Rizzo, L. V., Ro, C.-U., Ruckteschler, N., Sá, L. D.
A., de Oliveira Sá, M., Sales, C. B., dos Santos, R. M. N., Saturno, J., Schöngart, J., Sörgel, M., de Souza, C. M., de Souza, R. A. F., Su, H., Targhetta, N., Tóta, J., Trebs, I., Trumbore, S., van Eijck, A., Walter, D., Wang, Z., Weber, B., Williams, J., Winderlich, J., Wittmann, F., Wolff, S., and Yáñez-Serrano, A. M.: The Amazon Tall Tower Observatory (ATTO): overview of pilot measurements on ecosystem ecology, meteorology, trace gases, and aerosols, Atmos. Chem. Phys., 15, 10723-10776, https://doi.org/10.5194/acp-15-10723-2015, 2015.

Araújo, A. C., Nobre, A. D., Kruijt, B., Elbers, J. A., Dallarosa, R., Stefani, P., von Randow, C., Manzi, A. O., Culf, A. D., Gash, J. H. C., Valentini, R., and Kabat, P.: Comparative measurements of carbon dioxide fluxes from two nearby towers in a central Amazonian rainforest: The Manaus LBA site, J. Geophys. Res.-Atmos., 107, LBA 58-1-LBA 58-20, https://doi.org/10.1029/2001JD000676, 8090, 2002.

Berrisford, P., Dee, D., Poli, P., Brugge, R., Fielding, K., Fuentes, M., Kallberg, P., Kobayashi, S., Uppala, S., and Simmons, A.: The ERA-Interim archive, version 2.0, ERA Report Series, ERA Report, Reading, UK, 1, 2011.

Best, M. J., Pryor, M., Clark, D. B., Rooney, G. G., Essery, R. L. H., Ménard, C. B., Edwards, J. M., Hendry, M. A., Porson, A., Gedney, N., Mercado, L. M., Sitch, S., Blyth, E., Boucher, O., Cox, P. M., Grimmond, C. S. B., and Harding, R. J.: The Joint UK Land Environment Simulator (JULES), model description Part 1: Energy and water fluxes, Geosci. Model Dev., 4, 677-699, https://doi.org/10.5194/gmd-4-677-2011, 2011.

Betts, A. K., Gatti, L. V., Cordova, A. M., Dias, M. A. S., and Fuentes, J. D.: Transport of ozone to the surface by convective downdrafts at night, J. Geophys. Res.-Atmos., 107, LBA 13-1LBA 13-6, https://doi.org/10.1029/2000JD000158, 2002.

Brinkmann, W. and Ribeiro, M.: Air temperatures in Central Amazonia. III.-Vertical Temperature Distribution on a Clearcut Area and in a Secondary Forest near Manaus (Cold Front Conditions July 10 th. 1969), Acta Amazon., 2, 25-29, 1972.

Caraballo, P., Forsberg, B. R., Almeida, F. F. d., and Leite, R. G.: Diel patterns of temperature, conductivity and dissolved oxygen in an Amazon floodplain lake: description of a friagem phenomenon, Acta Limnologica Brasiliensia, 26, 318-331, 2014.

Cirino, G., Brito, J., Barbosa, H. M., Rizzo, L. V., Tunved, P., de Sá, S. S., Jimenez, J. L., Palm, B. B., Carbone, S., Lavric, J. V., Souza, R. A., Wolff, S., Walter, D., Tota, J., Oliveira, M. B., Martin, S. T., and Artaxo, P.: Observations of Manaus urban plume evolution and interaction with biogenic emissions in GoAmazon 2014/5, Atmos. Environ., 191, 513-524, https://doi.org/10.1016/j.atmosenv.2018.08.031, 2018.

Clark, D. B., Mercado, L. M., Sitch, S., Jones, C. D., Gedney, N., Best, M. J., Pryor, M., Rooney, G. G., Essery, R. L. H., Blyth, E., Boucher, O., Harding, R. J., Huntingford, C., and Cox, P. M.: The Joint UK Land Environment Simulator (JULES), model description - Part 2: Carbon fluxes and vegetation dynamics, Geosci. Model Dev., 4, 701-722, https://doi.org/10.5194/gmd-4701-2011, 2011.

Cohen, J. C. P., Dias, M. A. F. S., and Nobre, C. A.: Environmental Conditions Associated with Amazonian Squall Lines: A Case Study, Mon. Weather Rev., 123, 3163-3174, https://doi.org/10.1175/15200493(1995)123<3163:ECAWAS>2.0.CO;2, 1995. 
Cotton, W. R., Pielke Sr., R. A., Walko, R. L., Liston, G. E., Tremback, C. J., Jiang, H., McAnelly, R. L., Harrington, J. Y., Nicholls, M. E. Carrio, G. G., and McFadden, J. P.: RAMS 2001: Current status and future directions, Meteorol. Atmos. Phys., 82, 5-29, https://doi.org/10.1007/s00703-001-0584-9, 2003.

de Araújo, A. C., Dolman, A. J., Waterloo, M. J., Gash, J. H. C., Kruijt, B., Zanchi, F. B., de Lange, J. M. E., Stoevelaar, R., Manzi, A. O., Nobre, A. D., Lootens, R. N., and Backer J.: The spatial variability of $\mathrm{CO}_{2}$ storage and the interpretation of eddy covariance fluxes in central Amazonia, Agr. Forest Meteorol., 150, 226-237, https://doi.org/10.1016/j.agrformet.2009.11.005, 2010.

de Oliveira, P. J., da Rocha, E. J. P., Fisch, G., Kruijt, B., and Ribeiro, J. B. M.: Efeitos de um evento de friagem nas condições meteorológicas na Amazônia: um estudo de caso, Acta Amazon., 34, 613-619, https://doi.org/10.1590/S004459672004000400013, 2004.

de Souza, D. O. and Alvalá, R. C. d. S.: Observational evidence of the urban heat island of Manaus City, Brazil, Meteorol. Appl., 21, 186-193, https://doi.org/10.1002/met.1340, 2014.

Dias-Júnior, C. Q., Dias, N. L., Fuentes, J. D., and Chamecki, M.: Convective storms and non-classical low-level jets during high ozone level episodes in the Amazon region: An ARM/GOAMAZON case study, Atmos. Environ., 155, 199-209, https://doi.org/10.1016/j.atmosenv.2017.02.006, 2017.

dos Santos, M. J., Silva Dias, M. A., and Freitas, E. D.: Influence of local circulations on wind, moisture, and precipitation close to Manaus City, Amazon Region, Brazil, J. Geophys. Res.-Atmos., 119, 13-233, https://doi.org/10.1002/2014JD021969, 2014.

Fan, S.-M., Wofsy, S. C., Bakwin, P. S., Jacob, D. J., and Fitzjarrald, D. R.: Atmosphere-biosphere exchange of $\mathrm{CO}_{2}$ and $\mathrm{O} 3$ in the central Amazon forest, J. Geophys. Res.-Atmos., 95, 1685116864, https://doi.org/10.1029/JD095iD10p16851, 1990.

Fisch, G.: Camada Limite Amazônica: Aspectos Observacionais e de Modelagem, $180 \mathrm{f}$. tese (doutorado em meteorologia), Instituto Nacional de Pesquisas Espaciais, São José dos Campos, Brazil, 1996.

Fisch, G., Marengo, J. A., and Nobre, C. A.: Uma revisão geral sobre o clima da Amazônia, Acta Amazon., 28, 101-126, https://doi.org/10.1590/1809-43921998282126, 1998.

Freire, L. S., Gerken, T., Ruiz-Plancarte, J., Wei, D., Fuentes, J. D., Katul, G. G., Dias, N. L., Acevedo, O. C., and Chamecki, M.: Turbulent mixing and removal of ozone within an Amazon rainforest canopy, J. Geophys. Res.-Atmos., 122, 2791-2811, https://doi.org/10.1002/2016JD026009, 2017.

Freitas, R. G. and Freitas, S.: Estimativa operacional da umidade do solo para iniciação de modelos de previsão numérica da atmosfera parte I: descrição da metodologia e validação, Revista Brasileira de Meteorologia, 21, 1-15, 2006.

Freitas, S. R., Longo, K. M., Silva Dias, M. A. F., Chatfield, R., Silva Dias, P., Artaxo, P., Andreae, M. O., Grell, G., Rodrigues, L. F., Fazenda, A., and Panetta, J.: The Coupled Aerosol and Tracer Transport model to the Brazilian developments on the Regional Atmospheric Modeling System (CATT-BRAMS) - Part 1: Model description and evaluation, Atmos. Chem. Phys., 9, 2843 2861, https://doi.org/10.5194/acp-9-2843-2009, 2009.

Freitas, S. R., Panetta, J., Longo, K. M., Rodrigues, L. F., Moreira, D. S., Rosário, N. E., Silva Dias, P. L., Silva Dias, M. A. F., Souza, E. P., Freitas, E. D., Longo, M., Frassoni, A., Fazenda,
A. L., Santos e Silva, C. M., Pavani, C. A. B., Eiras, D., França, D. A., Massaru, D., Silva, F. B., Santos, F. C., Pereira, G., Camponogara, G., Ferrada, G. A., Campos Velho, H. F., Menezes, I., Freire, J. L., Alonso, M. F., Gácita, M. S., Zarzur, M., Fonseca, R. M., Lima, R. S., Siqueira, R. A., Braz, R., Tomita, S., Oliveira, V., and Martins, L. D.: The Brazilian developments on the Regional Atmospheric Modeling System (BRAMS 5.2): an integrated environmental model tuned for tropical areas, Geosci. Model Dev., 10, 189-222, https://doi.org/10.5194/gmd-10-189-2017, 2017.

Ganzeveld, L., Helmig, D., Fairall, C. W., Hare, J., and Pozzer, A.: Atmosphere-ocean ozone exchange: A global modeling study of biogeochemical, atmospheric, and waterside turbulence dependencies, Global Biogeochem. Cy., 23, GB4021, https://doi.org/10.1029/2008GB003301, 2009.

Gerken, T., Wei, D., Chase, R. J., Fuentes, J. D., Schumacher, C., Machado, L. A., Andreoli, R. V., Chamecki, M., de Souza, R. A. F., Freire, L. S., Jardine, A. B., Manzi, A. O., dos Santos, R. M. N., von Randow, C., dos Santos Costa, P., Stoy, P. C., Tóta, J., and Trowbridge, A. M.: Downward transport of ozone rich air and implications for atmospheric chemistry in the Amazon rainforest, Atmos. Environ., 124, 64-76, https://doi.org/10.1016/j.atmosenv.2015.11.014, 2016.

Jacob, D. J. and Wofsy, S. C.: Budgets of reactive nitrogen, hydrocarbons, and ozone over the Amazon forest during the wet season, J. Geophys. Res.-Atmos., 95, 16737-16754, https://doi.org/10.1029/JD095iD10p16737, 1990.

Kemenes, A., Forsberg, B. R., and Melack, J. M.: Methane release below a tropical hydroelectric dam, Geophys. Res. Lett., 34, L12809, https://doi.org/10.1029/2007GL029479, 2007.

Longo, K. M., Freitas, S. R., Andreae, M. O., Setzer, A., Prins, E., and Artaxo, P.: The Coupled Aerosol and Tracer Transport model to the Brazilian developments on the Regional Atmospheric Modeling System (CATT-BRAMS) - Part 2: Model sensitivity to the biomass burning inventories, Atmos. Chem. Phys., 10, 57855795, https://doi.org/10.5194/acp-10-5785-2010, 2010.

Marengo, J. A., Nobre, C. A., and Culf, A. D.: Climatic impacts of "friagens" in forested and deforested areas of the Amazon basin, J. Appl. Meteorol., 36, 1553-1566, https://doi.org/10.1175/1520 0450(1997)036<1553:CIOFIF>2.0.CO;2, 1997.

Martin, S. T., Artaxo, P., Machado, L. A. T., Manzi, A. O., Souza, R. A. F., Schumacher, C., Wang, J., Andreae, M. O., Barbosa, H. M. J., Fan, J., Fisch, G., Goldstein, A. H., Guenther, A., Jimenez, J. L., Pöschl, U., Silva Dias, M. A., Smith, J. N., and Wendisch, M.: Introduction: Observations and Modeling of the Green Ocean Amazon (GoAmazon2014/5), Atmos. Chem. Phys., 16, 47854797, https://doi.org/10.5194/acp-16-4785-2016, 2016.

Melo, A. M., Dias-Junior, C. Q., Cohen, J. C., Sá, L. D., Cattanio, J. H., and Kuhn, P. A.: Ozone transport and thermodynamics during the passage of squall line in Central Amazon, Atmos. Environ., 206, 132-143, https://doi.org/10.1016/j.atmosenv.2019.02.018, 2019.

Moreira, D. S., Freitas, S. R., Bonatti, J. P., Mercado, L. M., Rosário, N. M. É., Longo, K. M., Miller, J. B., Gloor, M., and Gatti, L. V.: Coupling between the JULES land-surface scheme and the CCATT-BRAMS atmospheric chemistry model (JULESCCATT-BRAMS1.0): applications to numerical weather forecasting and the $\mathrm{CO}_{2}$ budget in South America, Geosci. Model 
Dev., 6, 1243-1259, https://doi.org/10.5194/gmd-6-1243-2013, 2013.

Moura, M. A. L., Meixner, F. X., Trebs, I., Lyra, R. F. d. F., Andreae, M. O., and Nascimento Filho, M. F. d.: Evidência observacional das brisas do lago de Balbina (Amazonas) e seus efeitos sobre a concentração do ozônio, Acta Amazon., 34, 605-611, https://doi.org/10.1590/S0044-59672004000400012, 2004.

Pacifico, F., Folberth, G. A., Sitch, S., Haywood, J. M., Rizzo, L. V., Malavelle, F. F., and Artaxo, P.: Biomass burning related ozone damage on vegetation over the Amazon forest: a model sensitivity study, Atmos. Chem. Phys., 15, 2791-2804, https://doi.org/10.5194/acp-15-2791-2015, 2015.

Pöhlker, C., Walter, D., Paulsen, H., Könemann, T., RodríguezCaballero, E., Moran-Zuloaga, D., Brito, J., Carbone, S., Degrendele, C., Després, V. R., Ditas, F., Holanda, B. A., Kaiser, J. W., Lammel, G., Lavrič, J. V., Ming, J., Pickersgill, D., Pöhlker, M. L., Praß, M., Löbs, N., Saturno, J., Sörgel, M., Wang, Q., Weber, B., Wolff, S., Artaxo, P., Pöschl, U., and Andreae, M. O.: Land cover and its transformation in the backward trajectory footprint region of the Amazon Tall Tower Observatory, Atmos. Chem. Phys., 19, 8425-8470, https://doi.org/10.5194/acp19-8425-2019, 2019.

Prince, K. C. and Evans, C.: A Climatology of Extreme South American Andean Cold Surges, J. Appl. Meteorol. Clim., 57, 2297-2315, https://doi.org/10.1175/JAMC-D-18-0146.1, 2018.

Ricarte, R. M. D., Herdies, D. L., and Barbosa, T. F.: Patterns of atmospheric circulation associated with cold outbreaks in southern Amazonia, Meteorol. Appl., 22, 129-140, 2015.

Rizzo, L. V., Artaxo, P., Müller, T., Wiedensohler, A., Paixão, M., Cirino, G. G., Arana, A., Swietlicki, E., Roldin, P., Fors, E. O., Wiedemann, K. T., Leal, L. S. M., and Kulmala, M.: Long term measurements of aerosol optical properties at a primary forest site in Amazonia, Atmos. Chem. Phys., 13, 2391-2413, https://doi.org/10.5194/acp-13-2391-2013, 2013.

Rossato, L., Alvalá, R. d. S., and Tomasella, J.: Variação espaço-temporal da umidade do solo no Brasil: análise das condições médias para o período de 1971-1990, Revista Brasileira de Meteorologia, 19, 113-122, 2004.

Ruimy, A., Jarvis, P., Baldocchi, D., and Saugier, B.: $\mathrm{CO}_{2}$ fluxes over plant canopies and solar radiation: a review, Adv. Ecol. Res., 26, 1-68, https://doi.org/10.1016/S0065-2504(08)60063$\mathrm{X}, 1995$.

Rummel, U., Ammann, C., Kirkman, G. A., Moura, M. A. L., Foken, T., Andreae, M. O., and Meixner, F. X.: Seasonal variation of ozone deposition to a tropical rain forest in southwest Amazonia, Atmos. Chem. Phys., 7, 5415-5435, https://doi.org/10.5194/acp7-5415-2007, 2007.

Savijärvi, H. and Räisänen, P.: Long-wave optical properties of water clouds and rain, Tellus A, 50, 1-11, https://doi.org/10.3402/tellusa.v50i1.14508, 1998.
Savijärvi, H., Arola, A., and Räisänen, P.: Short-wave optical properties of precipitating water clouds, Q. J. Roy. Meteor. Soc., 123, 883-899, https://doi.org/10.1002/qj.49712354005, 1997.

Silva Dias, M., Dias, P. S., Longo, M., Fitzjarrald, D. R., and Denning, A. S.: River breeze circulation in eastern Amazonia: observations and modelling results, Theor. Appl. Climatol., 78, 111121, https://doi.org/10.1007/s00704-004-0047-6, 2004.

Sun, Z. and Shine, K. P.: Studies of the radiative properties of ice and mixed-phase clouds, Q. J. Roy. Meteor. Soc., 120, 111-137, https://doi.org/10.1002/qj.49712051508, 1994.

Thalman, R., de Sá, S. S., Palm, B. B., Barbosa, H. M. J., Pöhlker, M. L., Alexander, M. L., Brito, J., Carbone, S., Castillo, P., Day, D. A., Kuang, C., Manzi, A., Ng, N. L., Sedlacek III, A. J., Souza, R., Springston, S., Watson, T., Pöhlker, C., Pöschl, U., Andreae, M. O., Artaxo, P., Jimenez, J. L., Martin, S. T., and Wang, J.: CCN activity and organic hygroscopicity of aerosols downwind of an urban region in central Amazonia: seasonal and diel variations and impact of anthropogenic emissions, Atmos. Chem. Phys., 17, 11779-11801, https://doi.org/10.5194/acp-1711779-2017, 2017.

Thompson, G. and Eidhammer, T.: A Study of Aerosol Impacts on Clouds and Precipitation Development in a Large Winter Cyclone, J. Atmos. Sci., 71, 3636-3658, https://doi.org/10.1175/JAS-D-13-0305.1, 2014.

Thompson, G., Field, P. R., Rasmussen, R. M., and Hall, W. D.: Explicit Forecasts of Winter Precipitation Using an Improved Bulk Microphysics Scheme. Part II: Implementation of a New Snow Parameterization, Mon. Weather Rev., 136, 5095-5115, https://doi.org/10.1175/2008MWR2387.1, 2008.

Toon, O. B., McKay, C., Ackerman, T., and Santhanam, K.: Rapid calculation of radiative heating rates and photodissociation rates in inhomogeneous multiple scattering atmospheres, J. Geophys. Res.-Atmos., 94, 16287-16301, https://doi.org/10.1029/JD094iD13p16287, 1989.

Trebs, I., Mayol-Bracero, O. L., Pauliquevis, T., Kuhn, U., Sander, R., Ganzeveld, L., Meixner, F. X., Kesselmeier, J., Artaxo, P., and Andreae, M. O.: Impact of the Manaus urban plume on trace gas mixing ratios near the surface in the Amazon Basin: Implications for the $\mathrm{NO}-\mathrm{NO}_{2}-\mathrm{O}_{3}$ photostationary state and peroxy radical levels, J. Geophys. Res.-Atmos., 117, D05307, https://doi.org/10.1029/2011JD016386, 2012.

Viana, L. P. and Herdies, D. L.: Estudo de caso de um evento extremo de incursão de ar frio em julho de 2013 sobre a bacia amazônica brasileira, Revista Brasileira de Meteorologia, 33, 27-39, 2018. 